\title{
A Fundamental Role for the Nitric Oxide-G-Kinase Signaling Pathway in Mediating Intercellular $\mathrm{Ca}^{2+}$ Waves in Glia
}

\author{
Nicholas J. Willmott, Kay Wong, and Anthony J. Strong \\ Department of Clinical Neuroscience, Institute of Psychiatry, King's College London, London SE5 8AF
}

In this study, we highlight a role for the nitric oxide-cGMPdependent protein kinase (NO-G-kinase) signaling pathway in glial intercellular $\mathrm{Ca}^{2+}$ wave initiation and propagation. Addition of the NO donor molsidomine (100-500 $\mu \mathrm{M})$ or puffing aqueous $\mathrm{NO}$ onto primary glial cell cultures evoked an increase in $\left[\mathrm{Ca}^{2+}\right]_{\mathrm{i}}$ in individual cells and also local intercellular $\mathrm{Ca}^{2+}$ waves, which persisted after removal of extracellular $\mathrm{Ca}^{2+}$. High concentrations of ryanodine (100-200 $\mu \mathrm{M})$ and antagonists of the NO-G-kinase signaling pathway essentially abrogated the $\mathrm{NO}$-induced increase in $\left[\mathrm{Ca}^{2+}\right]_{i}$, indicating that $\mathrm{NO}$ mobilizes $\mathrm{Ca}^{2+}$ from a ryanodine receptor-linked store, via the NO-G-kinase signaling pathway. Addition of $10 \mu \mathrm{M}$ nicardipine to cells resulted in a slowing of the molsidomine-induced rise in $\left[\mathrm{Ca}^{2+}\right]_{i}$, and inhibition of $\mathrm{Mn}^{2+}$ quench of cytosolic fura-2 fluorescence mediated by a bolus application of $2 \mu \mathrm{m}$ aqueous
$\mathrm{NO}$ to cells, indicating that $\mathrm{NO}$ also induces $\mathrm{Ca}^{2+}$ influx in glia. Mechanical stress of individual glial cells resulted in an increase in intracellular NO in target and neighboring cells and intercellular $\mathrm{Ca}^{2+}$ waves, which were NO, cGMP, and G-kinase dependent, because incubating cells with nitric oxide synthase, guanylate cyclase, and G-kinase inhibitors, or NO scavengers, reduced $\Delta\left[\mathrm{Ca}^{2+}\right]_{i}$ and the rate of $\mathrm{Ca}^{2+}$ wave propagation in these cultures. Results from this study suggest that NO-Gkinase signaling is coupled to $\mathrm{Ca}^{2+}$ mobilization and influx in glial cells and that this pathway plays a fundamental role in the generation and propagation of intercellular $\mathrm{Ca}^{2+}$ waves in glia.

Key words: nitric oxide; glia; calcium waves; mobilization; influx; ryanodine receptors; nitric oxide synthase; DAF-2; phospholipase C; astrocytes
It is becoming increasingly apparent that intercellular $\mathrm{Ca}^{2+}$ waves might be the result of combined contributions of intracellular and extracellular $\mathrm{Ca}^{2+}$ signaling pathways in glial cells. One generally accepted mode of intercellular $\mathrm{Ca}^{2+}$ wave propagation involves the diffusion of $\mathrm{Ca}^{2+}$ mobilizing second messengers, including inositol-1,4,5-trisphosphate $\left(\mathrm{IP}_{3}\right)$ and $\mathrm{Ca}^{2+}$, across gap junctions (Nedergaard, 1994; Charles, 1998). Extracellular, gap junction-independent modes of $\mathrm{Ca}^{2+}$ signaling, involving the release of a diffusible messengers, also appear to operate in this particular system however, with ATP release from cells and $\mathrm{P}_{2}$ receptor-coupled elevation of $\left[\mathrm{Ca}^{2+}\right]_{i}$ having recently been suggested as a likely candidate (Cotrina et al., 1998; Guthrie et al., 1999). There are however other species that may participate as extracellular messengers in glial intercellular $\mathrm{Ca}^{2+}$ waves. There is increasing evidence that the highly diffusible messenger nitric oxide (NO) can induce $\mathrm{Ca}^{2+}$ mobilization in several cell types (Publicover et al., 1993; Willmott et al., 1995a,b,c; Clementi et al., 1996) either via the cGMP-dependent protein kinase (G-kinase)coupled activation of ADP-ribosyl cyclase, resulting in an increased synthesis of the potent $\mathrm{Ca}^{2+}$ mobilizing agent cyclic ADP-ribose (Willmott et al., 1996c; Clementi et al., 1996), or via direct nitrosylation of regulatory thiol groups of ryanodine receptors (Stoyanovsky et al., 1997).

\footnotetext{
Received Sept. 14, 1999; revised Nov. 22, 1999; accepted Nov. 29, 1999.

We thank Head First, the Golden Charitable Trust, the National Lottery Charities Board, King's NHS Healthcare Trust, and the Royal Society for supporting this work.

Correspondence should be addressed to Nicholas J. Willmott, Department of Clinical Neuroscience, Rooms E222 and E223, Institute of Psychiatry, King's College London, De Crespigny Park, Denmark Hill, London SE5 8AF. E-mail: spjnnjw@iop.kcl.ac.uk.

Copyright (C) 2000 Society for Neuroscience $\quad 0270-6474 / 00 / 201767-13 \$ 15.00 / 0$
}

Because NO synthesis by constitutive nitric oxide synthase (cNOS) is usually calcium-dependent (Moncada et al., 1991), a rise in $\left[\mathrm{Ca}^{2+}\right]_{\mathrm{i}}$ may serve to amplify NO production as previously reported (Publicover et al., 1993), and a high rate of potentially unrestricted diff usion for NO could also give rise or contribute to $\mathrm{Ca}^{2+}$ waves seen in many single cells and tissues (Berridge and Dupont, 1994). Therefore, considering the presence of $\mathrm{Ca}^{2+}$ dependent nitric oxide synthase in glia (Feinstein et al., 1994) and the possibility of cross-talk between NO and $\mathrm{Ca}^{2+}$ in these cells, this study investigated whether the NO-G-kinase signaling pathway is involved in $\mathrm{Ca}^{2+}$ homeostasis in glia and whether a hypothetical mobilization of $\mathrm{Ca}^{2+}$ by $\mathrm{NO}$ might initiate regenerative intercellular $\mathrm{Ca}^{2+}$ waves or contribute to intercellular $\mathrm{Ca}^{2+}$ wave propagation induced by mechanical stress of single glial cells in mixed glial-neuron cultures.

\section{MATERIALS AND METHODS}

Cell culture. Mixed glial-neuron primary cell cultures were prepared in a similar way as previously described (Goldman et al., 1989). Briefly, four forebrains of 1-2 d postnatal rats were dissected and transferred to $\mathrm{Ca} / \mathrm{Mg}$-free HBSS to which an equal volume of $0.25 \%$ trypsin- $1 \mathrm{~mm}$ EDTA solution (Life Technologies, Gaithersburg, MD) had been added. Forebrains were cut into small pieces and were incubated in this medium for $20 \mathrm{~min}$ at $37^{\circ} \mathrm{C}$ in a humidified atmosphere of $95 \%$ air and $5 \% \mathrm{CO}_{2}$. Forebrain pieces were transferred to a $15 \mathrm{ml}$ conical centrifugation tube (Corning, Corning, NY) and were washed with $4 \times 10 \mathrm{ml}$ aliquots of an equal mixture of DMEM and Ham's F-12. Finally pieces were suspended in $3 \mathrm{ml}$ of tissue culture medium consisting of $10 \%$ fetal calf serum and $90 \%$ of an equal mixture of DMEM and F-12, supplemented with 8 $\mathrm{mg} / \mathrm{ml} \mathrm{D}$-glucose, $20 \mathrm{U} / \mathrm{ml}$ penicillin, and $20 \mu \mathrm{g} / \mathrm{ml}$ streptomycin, and were triturated to homogeneity. Aliquots $(100 \mu \mathrm{l})$ of the resulting cell suspension were overlaid onto zero thickness glass coverslips in 6-well dishes that had been precoated with poly-L-lysine ( $2.5 \mu \mathrm{g} /$ coverslip) and laminin $\left(5 \mu \mathrm{g} /\right.$ coverslip). After a $3 \mathrm{hr}$ incubation at $37^{\circ} \mathrm{C}$ in a humidified atmosphere of $95 \%$ air and $5 \% \mathrm{CO}_{2}$, coverslips were flooded with $2 \mathrm{ml}$ of the above tissue culture medium and were maintained for 1-3 weeks 
in culture before use. Every $3 \mathrm{~d}, 1 \mathrm{ml}$ of culture medium was removed from coverslips and replaced with $1 \mathrm{ml}$ of fresh culture medium.

Immunocytochemistry. After 1 week in culture, immunocytochemical stains for glial fibrillary acidic protein (GFAP) and neurofilament protein (NFP) were used to quantify the proportion of astrocytes to neurons on the coverslips. Cultured coverslips were rinsed twice in HBSS (see drugs and solutions) at room temperature and were then fixed with $100 \%$ methanol at $-20^{\circ} \mathrm{C}$ for $10 \mathrm{~min}$. After two more washes in HBSS, coverslips were blocked with $10 \%$ normal goat serum (Sigma, Poole, UK) in PBS for $20 \mathrm{~min}$ at room temperature and were then incubated overnight at $4^{\circ} \mathrm{C}$ with primary antibody (rabbit IgG anti-GFAP, 1:100, or rabbit anti-neurofilament-200, 1:100; Sigma) in 1\% normal goat serum in PBS. Coverslips were then washed three times in PBS at room temperature and were incubated in the secondary antibody in PBS (Oregon Green 488-goat anti-rabbit, 1:50; Molecular Probes, Eugene, OR) for $45 \mathrm{~min}$ at room temperature. Coverslips were examined under epifluorescence using a Nikon Diaphot inverted microscope and excitation light of 490 $\mathrm{nm}$. Fluorescence images were captured with Axon Imaging Workbench software (Axon Instruments, Foster City, CA) using an intensified CCD (Prostab) and Axon Image Lightning frame grabber (Axon Instruments). Images were analyzed using Corel Photo-Paint (Corel Corporation).

Measurement of $\left[\mathrm{Ca}^{2+}\right]_{i}$ in mixed glial-neuron cell cultures. Intracellular and intercellular $\mathrm{Ca}^{2+}$ signaling were assessed in mixed glial-neuron primary cell cultures derived from the forebrains of neonatal rats $(1-2 \mathrm{~d}$ postnatal). Cell cultures were prepared as above and were maintained for $1-3$ weeks in a humidified atmosphere of $95 \%$ air and $5 \% \mathrm{CO}_{2}$ at $37^{\circ} \mathrm{C}$ before use. After 1 week, cultures were predominantly composed of astrocytes, as $>80 \%$ of cells showed cross-reaction with antibody to GFAP. Cells were loaded with $\mathrm{Ca}^{2+}$ indicator by incubation with $2 \mu \mathrm{M}$ of the AM ester of fura- 2 for $1 \mathrm{hr}$. Intracellular fluorescence was imaged at $22^{\circ} \mathrm{C}$ in HBSS, using a $40 \times$ oil-immersion objective and inverted microscope (Nikon Diaphot), equipped with a xenon arc lamp and excitation filter wheel system (Cairn) and intensified CCD (Prostab) interfaced to a Pentium II computer with an Axon Image Lightning 2000 frame grabber (Axon Instruments), digitizing at a 10-bit grayscale resolution. A low temperature was used for $\mathrm{Ca}^{2+}$ imaging experiments because fura- 2 readily compartmentalizes into cellular organelles at higher, physiological temperatures in these cell preparations. Cells were maintained in a static, open chamber throughout experiments. Free cytosolic $\mathrm{Ca}^{2+}$ was quantified by taking the ratio of fluorescence intensities at excitation wavelengths 340 and $380 \mathrm{~nm}$, using an emission wavelength of $510 \mathrm{~nm}$. Pairs of 340 and $380 \mathrm{~nm}$ images were captured every $2.5 \mathrm{sec}$, and ratio images were calculated using Axon Imaging Workbench software (Axon Instruments). Standard $\mathrm{CaCl}_{2}$ solutions were used to calibrate the system for measurements with fura-2, and viscosity corrections were made (Poenie, 1990). Cellular $\mathrm{Ca}^{2+}$ response parameters were compared for statistical significance using Student's $t$ test for unpaired observations.

Assessment of $\mathrm{Ca}^{2+}$ influx by the manganese quench of cytosolic fura-2 fluorescence. Cells were loaded with the AM ester of fura- 2 as above. Manganese quench of glial cell cytosolic fura-2 fluorescence was monitored using an excitation wavelength of $365 \mathrm{~nm}$, with a similar microscope-based imaging system as for $\mathrm{Ca}^{2+}$ measurements. Fluorescence images were captured every $8 \mathrm{sec} . \mathrm{Mn}^{2+}$ was added to the cell chamber, and the effect of bolus additions of aqueous NO and/or thapsigargin on $\mathrm{Mn}^{2+}$ quench of cytosolic fura-2 fluorescence was assessed in glial cells.

Monitoring cytosolic nitric oxide production in mixed glial-neuron cell cultures. Changes in cytosolic NO concentration were monitored in glial-neuron primary cell cultures using the recently described single excitation wavelength, fluorescent NO probe DAF-2 (Kojima et al., 1998). Cells were loaded with NO indicator by incubation with $10 \mu \mathrm{M}$ of DAF-2 DA for $1 \mathrm{hr}$. Intracellular fluorescence was imaged at $22^{\circ} \mathrm{C}$ in HBSS, using a $40 \times$ oil-immersion objective and inverted microscope (Nikon Diaphot), equipped with a xenon arc lamp and excitation filter wheel system (Cairn), and 12-bit interline CCD (5 MHz Micromax; Princeton Instruments, Princeton, NJ) interfaced to a Pentium II computer. Cells were maintained in a static, open chamber throughout experiments. Free cytosolic NO was monitored by ratioing the change in fluorescence intensity at an excitation wavelength of $490 \mathrm{~nm}$ with the initial fluorescence intensity at $490 \mathrm{~nm}\left(\Delta F / F_{0}\right)$, using an emission wavelength of $515 \mathrm{~nm}$. Because DAF-2 is not a quantitative probe, no attempt was made to calibrate DAF-2 fluorescence with standard solutions of aqueous NO. Fluorescence images were captured every $2.5 \mathrm{sec}$, and ratio
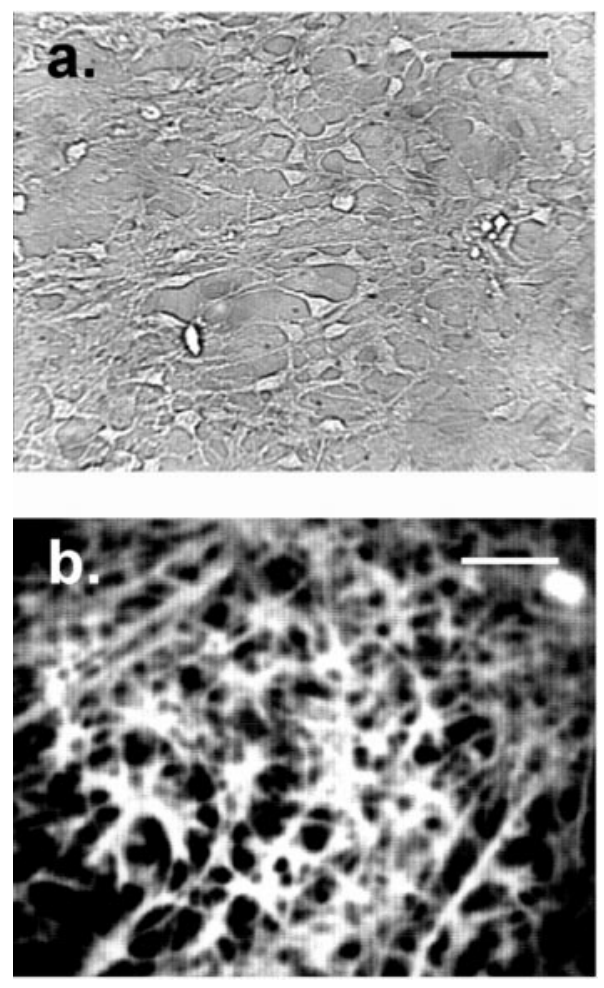

Figure 1. Mixed glial-neuron cultures used in the experiments. $a$, Typical example of a mixed glial-neuron cell preparation used in the experiments. The image of $a$ was obtained with standard microscope illumination and a $40 \times$ oil immersion objective. $b$, After 1 week in culture, cells were predominantly glial, because $>80 \%$ cross-reacted with an antibody to GFAP that was tagged with the fluorescent dye Oregon Green. The image of $b$ was acquired using epifluorescence (490 nm excitation). Scale bars, $50 \mu \mathrm{m}$.

images were calculated using Axon Imaging Workbench software (Axon Instruments).

Drugs and solutions. Experiments were performed in HBSS, pH 7.2, containing (in mM): $137 \mathrm{NaCl}, 5.4 \mathrm{KCl}, 1.3 \mathrm{CaCl}_{2}, 0.83 \mathrm{MgSO}_{4}, 0.42$ $\mathrm{Na}_{2} \mathrm{HPO}_{4}, 0.44 \mathrm{KH}_{2} \mathrm{PO}_{4}, 4.2 \mathrm{NaHCO}_{3}$, and 5 glucose. For experiments performed in nominally $\mathrm{Ca}^{2+}$-free medium, $\mathrm{CaCl}_{2}$ was omitted from the above, and $0.5 \mathrm{~mm}$ EGTA was added, yielding a free $\mathrm{Ca}^{2+}$ concentration of $\sim 10 \mathrm{nM}$. Nitric oxide gas was from Aldrich (Milwaukee, WI). Aqueous nitric oxide was prepared in HBSS, and its concentration was estimated according to a previously described method (Willmott et al., 1996c). HAM's F-12 medium, DMEM, fetal calf serum, penicillin, and streptomycin were from Life Technologies (Glasgow, UK). Fura-2 AM was from Molecular Probes. Rp-8-pCPT-cGMPS was from Biolog Life Science Institute (Hamburg, Germany). LY 83583, $N^{\mathrm{G}}$-methyl-L-arginine (LNMMA), ryanodine, thapsigargin, DAF-2 DA and 2-phenyl-4,4,5,5tetramethyl-imidazoline-1-oxyl 3-oxide (PTIO) were from Calbiochem (La Jolla, CA). All other drugs were from Sigma.

\section{RESULTS}

After 1 week in culture, cells were predominantly glial, because $>80 \%$ cross-reacted with an antibody to GFAP that was tagged with the fluorescent dye Oregon Green (Fig. 1). It was possible to discriminate between glial and neuronal cells in our mixed glialneuron cultures. Neuronal cells, which cross-reacted with antibody to neurofilament protein, were rounder in shape with fewer processes and appeared phase bright under microscope illumination compared to glia. These differences assisted our selection of cells in mechanical stimulation experiments, in which only individual glial cells were mechanically stressed. In all experiments, uniform cell 

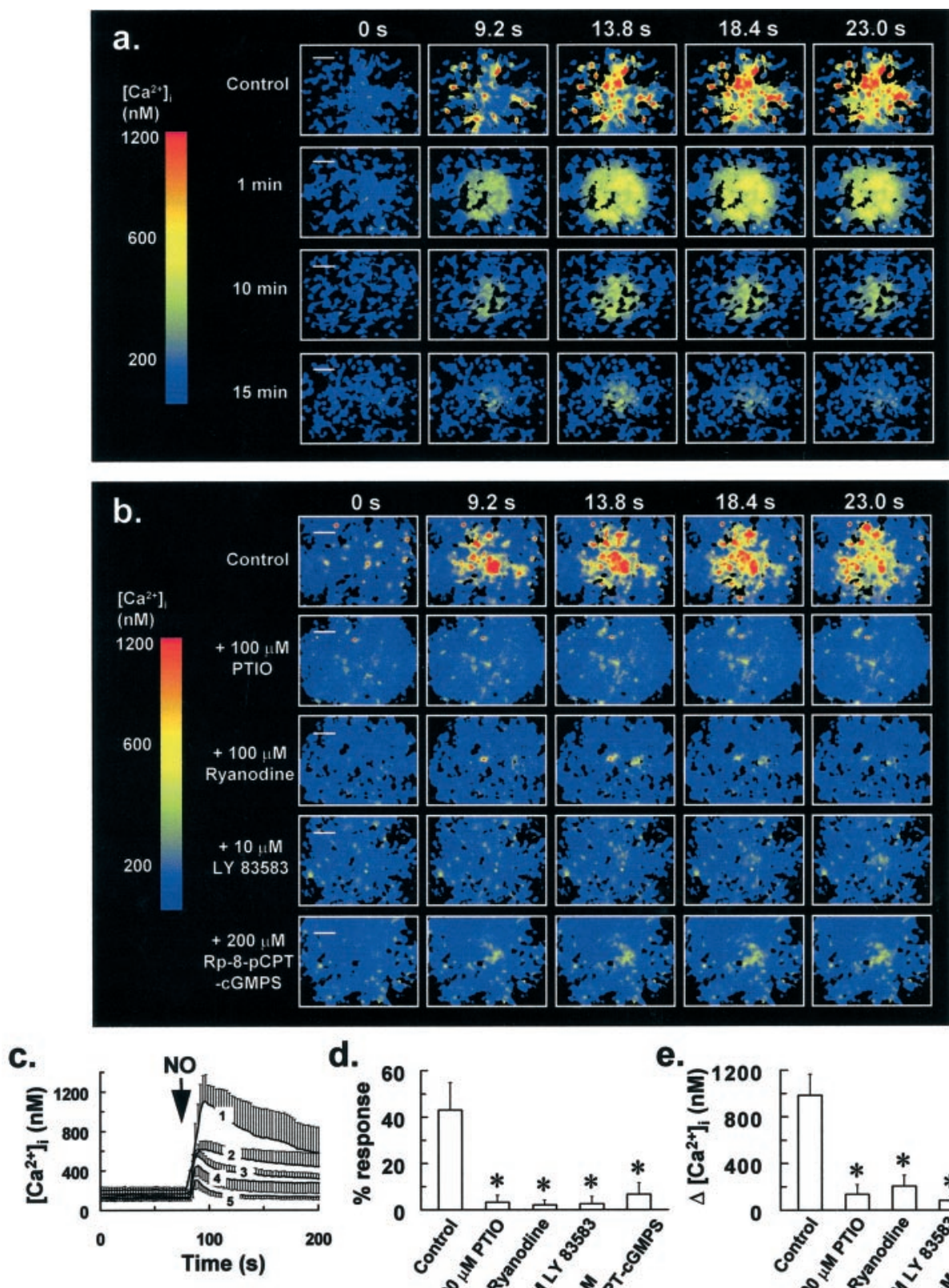

d.

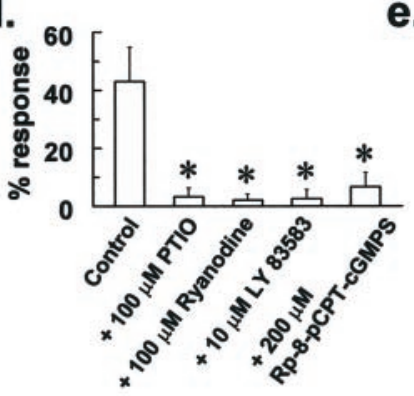

e.

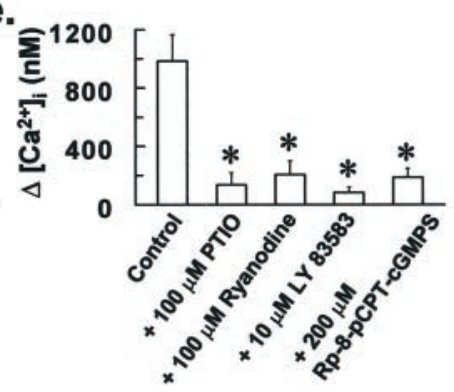

Figure 2. $\mathrm{NO}$ induces $\mathrm{Ca}^{2+}$ mobilization in glia via the NO-G-kinase signaling pathway. $a$, Top panel (Control), Fluorescence ratio images showing an increase in $\left[\mathrm{Ca}^{2+}\right]_{\mathrm{i}}$ induced by puffing aqueous $\mathrm{NO}$ onto glial cells at $t=0 \mathrm{sec}$. The pipette concentration of $\mathrm{NO}$ was 35 $\mu \mathrm{M}$, and puff duration was $100 \mathrm{msec}$, resulting in a reproducible delivery of 50 pl (calibrated by measuring injected droplet size in oil). Bottom panels of $a$ are the same as above, except cells were incubated in a nominally $\mathrm{Ca}^{2+}$-free medium $\left(0 \mathrm{Ca}^{2+}, 0.5 \mathrm{~mm}\right.$ EGTA) for the indicated times before $\mathrm{NO}$ application. This resulted in intracellular $\mathrm{Ca}^{2+}$ store depletion and a gradual reduction in the $\Delta\left[\mathrm{Ca}^{2+}\right]_{\mathrm{i}}$ induced by NO $(a)$. Fluorescence ratio image sequences in $a$ are representative of five separate experiments in different coverslips for each treatment. $b$, Pretreatment of cells with $100 \mu \mathrm{M}$ PTIO for $5 \mathrm{~min}, 100 \mu \mathrm{M}$ ryanodine for $30 \mathrm{~min}, 10 \mu \mathrm{M} \mathrm{LY} 83583$ for 1 min, or $300 \mu \mathrm{M}$ Rp-8-pCPT-cGMPS for 30 min resulted in the abrogation of the increase in $\left[\mathrm{Ca}^{2+}\right]_{\mathrm{i}}$ induced by a puff of aqueous NO at $t=0$, as in $a$. Fluorescence ratio image sequences of $b$ are representative of at least six separate experiments in different coverslips, for untreated control cells and each of the above drug pretreatments. Scale bars, 50 $\mu \mathrm{m}$. Traces in $c$ were derived from the experiments of $a$ and represent the mean $\left[\mathrm{Ca}^{2+}\right]_{\mathrm{i}}$ for at least 53 responding cells from five separate experiments, which demonstrated an increase in $\left[\mathrm{Ca}^{2+}\right]_{\mathrm{i}}$ after administration of a puff of NO (arrow) as in $a$. From top to bottom in $c$, trace 1 represents the control response to a puff of NO for cells maintained in normal HBSS, whereas traces 2-5 represent responses to a puff of NO after transfer of cells to a nominally $\mathrm{Ca}^{2+}$-free medium for $1,5,10$, and 15 $\mathrm{min}$, respectively, before NO application. $d$, Graph derived from the experiments of $b$ showing a reduction in the percentage of cells in a $350 \times 300 \mu \mathrm{m}$ field that demonstrated a rise in $\left[\mathrm{Ca}^{2+}\right]_{\mathrm{i}}$ to a puff of aqueous NO, after pretreatment of cells with the drugs of $b . e$, Graph derived from the experiments of $b$ showing a reduction in $\Delta\left[\mathrm{Ca}^{2+}\right]_{i}$ for cells that responded to a puff of aqueous NO after pretreatment of cells with the drugs of $b$. Bars in $d$ and $e$ indicate the means of at least six separate estimations. Error bars in $c-e$ indicate SD ( ${ }^{*} p<0.05$ vs control value; Student's $t$ test for unpaired observations).

regions were chosen that were predominantly glial $(\sim 80-90 \%)$ and that contained at least 200 cells in a $350 \times 300 \mu \mathrm{m}$ field.

\section{Nitric oxide induces $\mathrm{Ca}^{2+}$ mobilization in glial cells via the NO-G-kinase signaling pathway}

The effect of $\mathrm{NO}$ on $\left[\mathrm{Ca}^{2+}\right]_{\mathrm{i}}$ of mixed glial-neuron cultures was assessed. A puff of aqueous NO induced large transient increases in $\left[\mathrm{Ca}^{2+}\right]_{\mathrm{i}}$ of up to $1 \mu \mathrm{M}$ and often triggered localized intercellular $\mathrm{Ca}^{2+}$ waves involving groups of up to 20 cells (Fig. $2 a, b$, control sequences of ratio images). In puff experiments, the microinjection pipette containing aqueous $\mathrm{NO}$ at a concentration of $35 \mu \mathrm{M}$ was positioned centrally, at a distance of $150 \mu \mathrm{m}$ above the cells. Puff duration was $100 \mathrm{msec}$, resulting in a reproducible delivery of $50 \mathrm{pl}$ (calibrated by measuring injected droplet size in oil). By the same procedure, puffing solely HBSS onto cells did not affect $\left[\mathrm{Ca}^{2+}\right]_{\mathrm{i}}$. On transferring cells to a nominally $\mathrm{Ca}^{2+}$-free medium $\left(0 \mathrm{Ca}^{2+}, 0.5 \mathrm{~mm}\right.$ EGTA), a puff of NO induced a smaller increase in $\left[\mathrm{Ca}^{2+}\right]_{\mathrm{i}}$, which diminished with increasing length of incubation in this medium (Fig. 2a,c). This was attributable to intracellular $\mathrm{Ca}^{2+}$ store depletion, because addition of $1 \mu \mathrm{M}$ ionomycin to cells maintained in this $\mathrm{Ca}^{2+}$-depleted medium for $15 \mathrm{~min}$ increased $\left[\mathrm{Ca}^{2+}\right]_{\mathrm{i}}$ by only $150-220 \mathrm{~nm}$ (data not shown). These observations indicate that NO induces $\mathrm{Ca}^{2+}$ mobilization in glial cells.

Pretreating cells with $100 \mu \mathrm{M}$ of the cell-permeant NO scavenger PTIO for 5 min essentially abrogated the increase in $\left[\mathrm{Ca}^{2+}\right]_{\mathrm{i}}$ after a puff of NO (Fig. $2 b, d, e)$, underscoring a specific effect for 

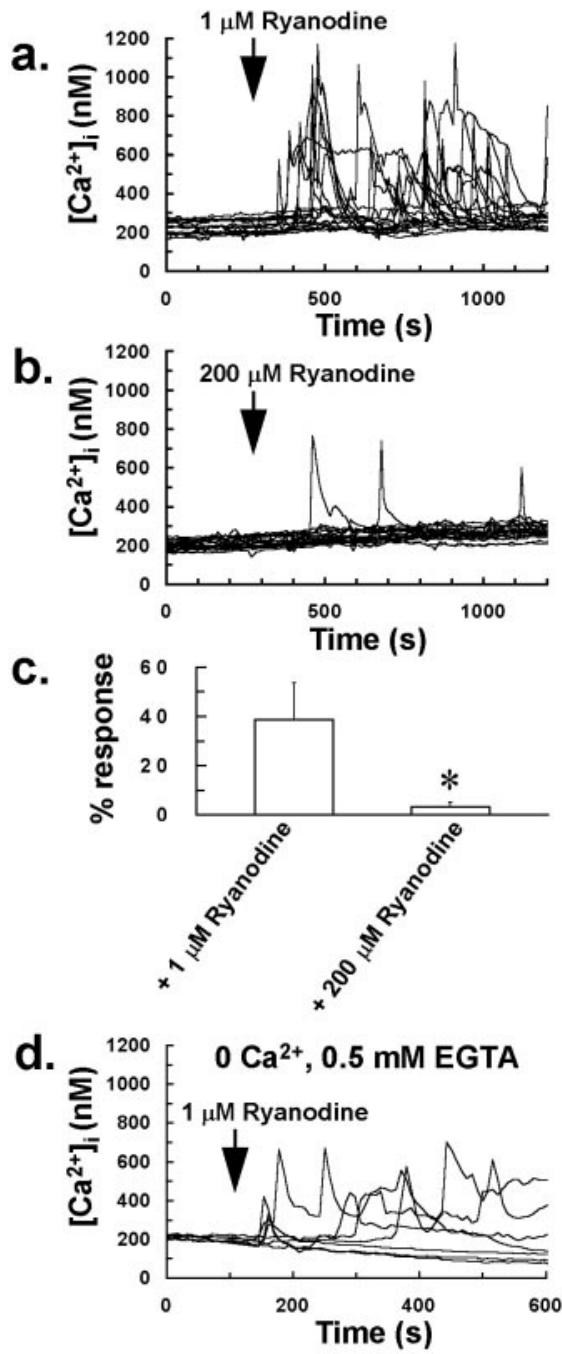

Figure 3. A low concentration of ryanodine induces $\mathrm{Ca}^{2+}$ mobilization and intracellular $\mathrm{Ca}^{2+}$ oscillations in glia. $a$, Application of a low concentration of ryanodine $(1 \mu \mathrm{M})$ to mixed glial-neuron cultures induced intracellular $\mathrm{Ca}^{2+}$ oscillations in $39 \%$ of cells located in quiescent cell regions, in which there was no random change in $\left[\mathrm{Ca}^{2+}\right]_{i}$ before ryanodine application. $b$, In contrast, application of a high, antagonizing concentration of ryanodine $(200 \mu \mathrm{M})$ to mixed glial-neuron cultures induced intracellular $\mathrm{Ca}^{2+}$ oscillations in only $3 \%$ of cells located in quiescent cell regions. Traces in $a$ and $b$ represent $\left[\mathrm{Ca}^{2+}\right]_{\mathrm{i}}$ of 20 cells chosen at random from a $350 \times 300 \mu \mathrm{m}$ field and are typical of four separate experiments for 1 and $200 \mu \mathrm{M}$ ryanodine treatments. $c$, Graph showing the percentage of cells in a $350 \times 300 \mu \mathrm{m}$ field that demonstrated a rise in $\left[\mathrm{Ca}^{2+}\right]_{\mathrm{i}}$ to low $(1 \mu \mathrm{M})$ and high $(200 \mu \mathrm{M})$ concentrations of ryanodine. Bars in $c$ indicate the mean of four separate estimations, and error bars indicate $\mathrm{SD}\left({ }^{*} p<\right.$ 0.05 vs $1 \mu \mathrm{M}$ ryanodine value; Student's $t$ test for unpaired observations). $d$, Intracellular $\mathrm{Ca}^{2+}$ oscillations to $1 \mu \mathrm{M}$ ryanodine were still observed in glial cells after transferring cultures to a nominally $\mathrm{Ca}^{2+}$-free medium, indicating that a low concentration of ryanodine induces $\mathrm{Ca}^{2+}$ mobilization from intracellular stores in glia.

$\mathrm{NO}$ on intracellular $\mathrm{Ca}^{2+}$ release in glia. It has previously been reported that NO-induced $\mathrm{Ca}^{2+}$ mobilization is ryanodine receptor (RyR)-linked in several cell types (Publicover et al., 1993; Willmott et al., 1995a; Willmott et al., 1996c). To test for the involvement of a RyR-mediated $\mathrm{Ca}^{2+}$ release mechanism, cells were preincubated with an antagonizing concentration of ryanodine before NO application. The binding of ryanodine to RyRs is practically irreversible, and at doses $>50 \mu \mathrm{M}$, the associated $\mathrm{Ca}^{2+}$ conductance is inhibited (Rousseau et al., 1987; Zimanyi et al.,
1992). Because of its slow association kinetics (Pessah et al., 1987), a ryanodine concentration of $100 \mu \mathrm{M}$ and preincubation of 30 min was used. This treatment had a negligible effect on $\left[\mathrm{Ca}^{2+}\right]_{i}$ of glial cells in our experiments and did not result in $\mathrm{Ca}^{2+}$ store depletion, because addition of $1 \mu \mathrm{M}$ ionomycin to cells immediately after transfer to a $\mathrm{Ca}^{2+}$-free medium resulted in a substantial increase in $\left[\mathrm{Ca}^{2+}\right]_{\mathrm{i}}$ of $400-600 \mathrm{~nm}$ (data not shown), similar to that of untreated control cells. For glial cells preincubated with this antagonizing concentration of ryanodine, the increase in $\left[\mathrm{Ca}^{2+}\right]_{\mathrm{i}}$ to a puff of NO was almost completely abrogated (Fig. $2 b, d, e)$.

Similarly, pretreating cells with the guanylate cyclase inhibitor LY $83583(10 \mu \mathrm{M})$ for $1 \mathrm{~min}$ essentially abolished the NO-induced increase in $\left[\mathrm{Ca}^{2+}\right]_{\mathrm{i}}$, whereas preincubating cells with the G-kinase inhibitor Rp-8-pCPT-cGMPS $(200 \mu \mathrm{M})$ for $30 \mathrm{~min}$ substantially reduced this response, with $<10 \%$ of cells demonstrating an increase in $\left[\mathrm{Ca}^{2+}\right]_{i}$ of only $200 \mathrm{nM}$, after a puff of NO (Fig. $2 b, d, e$ ). Treating cells with the above agents had no effect on $\left[\mathrm{Ca}^{2+}\right]_{\mathrm{i}}$ and did not cause $\mathrm{Ca}^{2+}$ store depletion during the preincubation period. These data strongly suggest that NO mobilizes $\mathrm{Ca}^{2+}$ from a RyR-linked $\mathrm{Ca}^{2+}$ store via the NO-Gkinase signaling pathway in glial cells.

\section{Evidence for ryanodine receptor-linked $\mathrm{Ca}^{2+}$ release in glia}

Bolus application of a low, agonizing concentration of ryanodine $(1 \mu \mathrm{M})$ onto quiescent glia resulted in intracellular $\mathrm{Ca}^{2+}$ oscillations in $39 \%$ of glial cells (Fig. $3 a$ ) and localized intercellular $\mathrm{Ca}^{2+}$ waves involving groups of up to 20 cells. These oscillations to $1 \mu \mathrm{M}$ ryanodine were still observed in some cells after transferring cultures to a nominally $\mathrm{Ca}^{2+}$-free medium (Fig. $3 d$ ), indicating that a low concentration of ryanodine induces $\mathrm{Ca}^{2+}$ mobilization in glia. Data are consistent with a previous study, which suggested the presence of RyR-coupled $\mathrm{Ca}^{2+}$ pools in astrocytes, as a low, agonizing concentration of ryanodine (10 $\mu \mathrm{M}$ ) induced $\mathrm{Ca}^{2+}$ store depletion in these cells (Giaume and Venance, 1998). In direct contrast, application of an antagonizing concentration of ryanodine $(200 \mu \mathrm{M})$ onto quiescent cells had a negligible effect on $\left[\mathrm{Ca}^{2+}\right]_{i}$ of glia, with only $3 \%$ of cells demonstrating intracellular $\mathrm{Ca}^{2+}$ oscillations to this treatment over a 20 min time period (Fig. $3 b, c$ ). Furthermore, this treatment did not result in a detectable depletion of intracellular $\mathrm{Ca}^{2+}$ stores, because addition of $1 \mu \mathrm{M}$ ionomycin to cells after transfer to a nominally $\mathrm{Ca}^{2+}$-free medium resulted in a substantial increase in $\left[\mathrm{Ca}^{2+}\right]_{\mathrm{i}}$ of $400-600 \mathrm{nM}$, comparable to that of untreated control cells.

\section{Nitric oxide induces $\mathrm{Ca}^{2+}$ influx in glial cells, which is inhibited by nicardipine}

Bolus addition of the NO donor molsidomine (100-500 $\mu \mathrm{M})$ to the incubation bath resulted in a heterogeneous increase in $\left[\mathrm{Ca}^{2+}\right]_{\mathrm{i}}$ of glial cells and also localized intercellular $\mathrm{Ca}^{2+}$ waves involving groups of 5-15 cells, similar to those observed with puffs of aqueous NO and $1 \mu \mathrm{M}$ ryanodine. With application of $500 \mu \mathrm{M}$ molsidomine, $\left[\mathrm{Ca}^{2+}\right]_{\mathrm{i}}$ started to increase in cells after a latent period of $\sim 400 \mathrm{sec}$. Responses consisted of an initial slow increase in $\left[\mathrm{Ca}^{2+}\right]_{\mathrm{i}}$, followed by a much faster burst phase (Fig. $4 a$ ), with $>90 \%$ of glial cells demonstrating an increase in $\left[\mathrm{Ca}^{2+}\right]_{i}$ to $500 \mu \mathrm{M}$ molsidomine. This latent effect for molsidomine (Fig. 4a) could possibly be attributable to slow or delayed NO donation. A positive feedback mechanism could also be responsible for the above effect, but considering the lack of a significantly delayed 


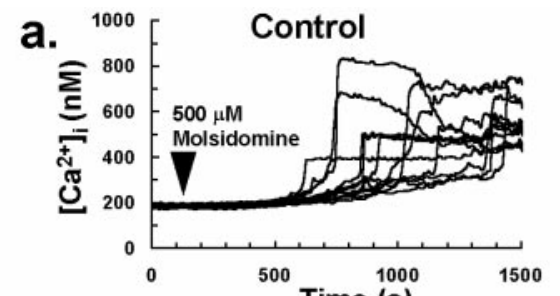

C.
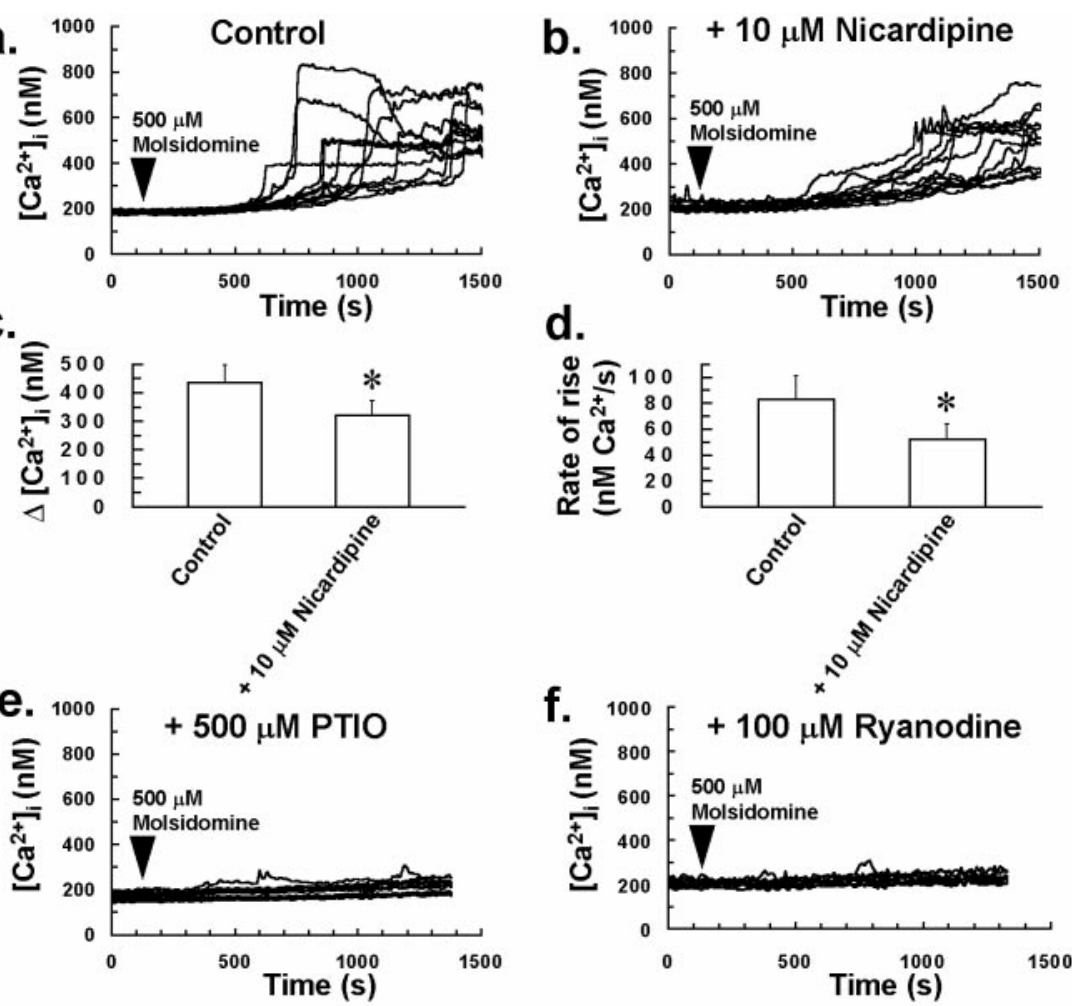

d.
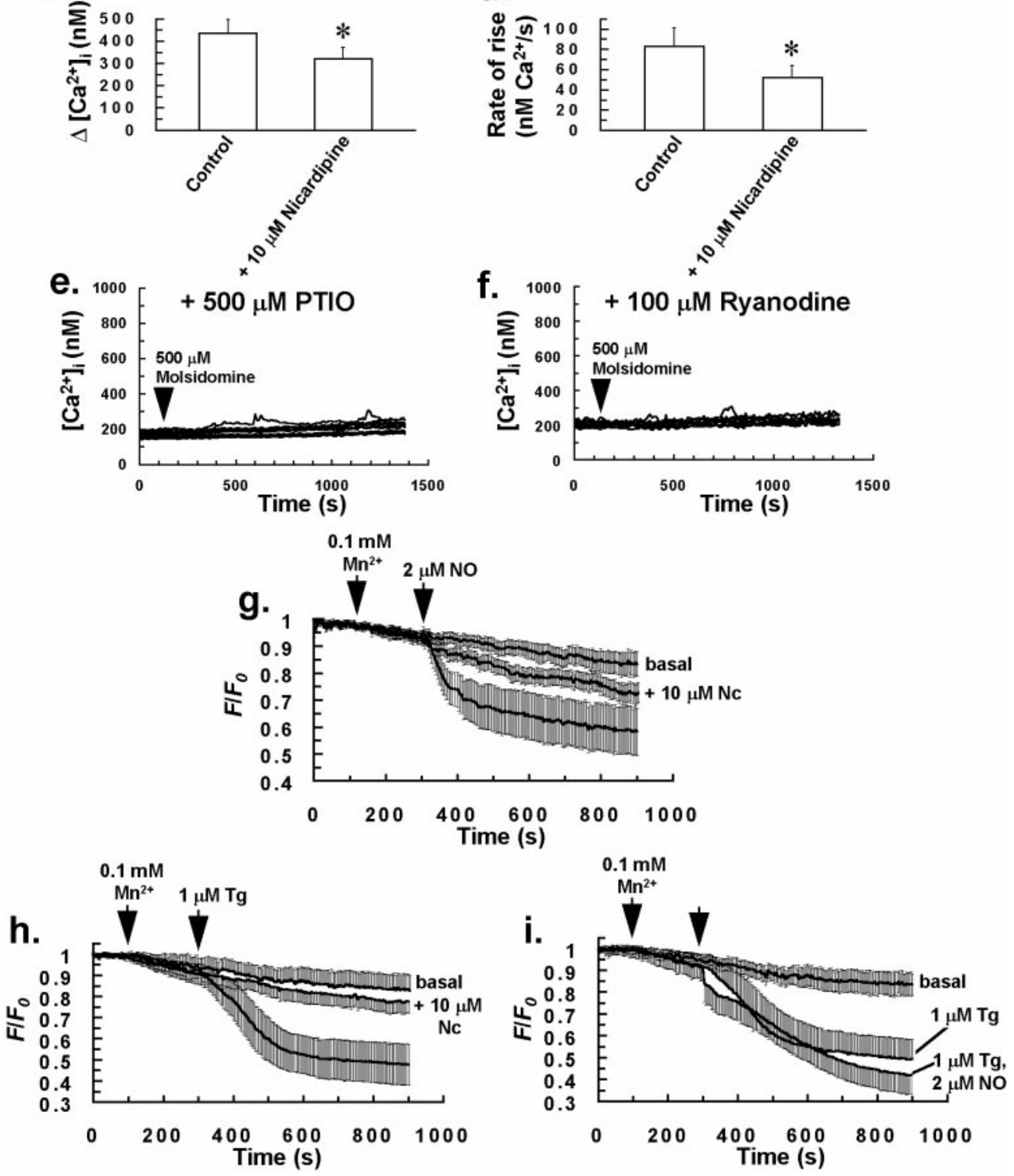

Figure 4. NO induces $\mathrm{Ca}^{2+}$ influx in glia that is nicardipine-sensitive. The rate of rise and magnitude of increases in $\left[\mathrm{Ca}^{2+}\right]_{\mathrm{i}}$ induced by bolus addition of the NO donor molsidomine to the incubation bath $(a)$ were reduced by pretreating cells with $10 \mu \mathrm{M}$ nicardipine for 5 min $(b) . c$, Graph derived from the experiments of $a$ and $b$ showing a reduction in $\Delta\left[\mathrm{Ca}^{2+}\right]_{i}$ for cells that responded to $500 \mu \mathrm{M}$ molsidomine, after pretreatment of cells with $10 \mu \mathrm{M}$ nicardipine. $d$, Graph derived from the experiments of $a$ and $b$ showing a reduction in the rate of rise of $\left[\mathrm{Ca}^{2+}\right]_{i}$ of the final burst phase, for cells that demonstrated an increase in $\left[\mathrm{Ca}^{2+}\right]_{\mathrm{i}}$ to $500 \mu \mathrm{M}$ molsidomine, after pretreatment of cells with $10 \mu \mathrm{M}$ nicardipine. Bars in $c$ and $d$ indicate the means of at least four separate estimations, and error bars indicate $\mathrm{SD}\left({ }^{*} p<0.05\right.$ vs control value; Student's $t$ test for unpaired observations). Molsidomine-induced elevations in $\left[\mathrm{Ca}^{2+}\right]_{\mathrm{i}}$ were completely abrogated by pretreating cells with $500 \mu \mathrm{M}$ PTIO for $5 \mathrm{~min}(e)$ or $100 \mu \mathrm{M}$ ryanodine for $30 \mathrm{~min}(f)$ before molsidomine application (arrow). Traces in $a, b, e$, and $f$ are from 12 individual cells and are representative of at least four separate experiments for each of the above treatments. Bolus application of $2 \mu \mathrm{M}$ aqueous NO $(g)$ or $1 \mu \mathrm{M} \mathrm{Tg}(h)$ to cells resulted in $\mathrm{Mn}^{2+}$ quench of cytosolic fura-2 fluorescence (365 nm excitation) that was abrogated by pretreating cells with $10 \mu \mathrm{M}$ nicardipine ( $N c$; center traces) for $5 \mathrm{~min}$. There was no significant additive effect on the $\mathrm{Mn}^{2+}$ quench of cytosolic fura-2 fluorescence with a combined application of NO and $\mathrm{Tg}$, compared to Tg alone (i), suggesting that $\mathrm{NO}$ acts on the same $\mathrm{Ca}^{2+}$ influx pathway as Tg in glial cells. All traces in $g-i$ represent the mean normalized fluorescence intensity of at least 200 cells from four separate experiments for each of the above treatments. Error bars indicate SD. For measurements of basal $\mathrm{Mn}^{2+}$ quench of cytosolic fura-2 fluorescence (top traces) in $g-i$, no drugs were added to cells. rise in $\left[\mathrm{Ca}^{2+}\right]_{\mathrm{i}}$ of cells after a puff of aqueous NO (Fig. $2 c$ ), the former suggestion may seem a more appropriate explanation. The rate of rise for increases in $\left[\mathrm{Ca}^{2+}\right]_{i}$ induced by molsidomine was reduced by pretreating cells with $10 \mu \mathrm{M}$ nicardipine for $5 \mathrm{~min}$ (Fig. 4b,d), with cells demonstrating increases in $\left[\mathrm{Ca}^{2+}\right]_{\mathrm{i}}$ with a prolonged initial slow phase, followed by a burst phase that was often slower and reduced in magnitude compared to control cells (Fig. $4 b-d$ ). Results suggest that NO induces $\mathrm{Ca}^{2+}$ influx in glia, which is nicardipine-sensitive. As for aqueous NO, molsidomineinduced elevations in $\left[\mathrm{Ca}^{2+}\right]_{\mathrm{i}}$ were essentially abrogated by pretreating cells with $500 \mu \mathrm{M}$ PTIO for 5 min (Fig. 4e) or $100 \mu \mathrm{M}$ ryanodine for $30 \mathrm{~min}$ (Fig. $4 f$ ) before molsidomine application.
Further evidence for $\mathrm{NO}$ inducing $\mathrm{Ca}^{2+}$ influx in glial cells was derived from $\mathrm{Mn}^{2+}$ quench experiments. It is generally accepted that $\mathrm{Mn}^{2+}$ can enter cells along with $\mathrm{Ca}^{2+}$ via store-operated $\mathrm{Ca}^{2+}$ channels, which open after $\mathrm{Ca}^{2+}$ store depletion (Putney, 1990) and also probably via other $\mathrm{Ca}^{2+}$ or nonselective cation channels. The endoplasmic reticulum (ER) $\mathrm{Ca}^{2+}$-ATPase inhibitor thapsigargin ( $\mathrm{Tg}$ ) is well established as an agent that activates store-operated $\mathrm{Ca}^{2+}$ influx in cells by depleting intracellular $\mathrm{Ca}^{2+}$ stores (Zweifach and Lewis, 1993; Petersen and Berridge, 1994). Bolus application of $2 \mu \mathrm{M}$ aqueous NO (Fig. $4 g$ ), or $1 \mu \mathrm{M}$ $\mathrm{Tg}$ (Fig. $4 h$ ), to cells resulted in $\mathrm{Mn}^{2+}$ quench of cytosolic fura-2 fluorescence, which was almost completely prevented by pretreat- 
Figure 5. Intercellular $\mathrm{Ca}^{2+}$ waves induced by mechanical stress of single glial cells. $a$, Top panel (control), Mechanical stress of a single glial cell (arrow) evoked an intercellular $\mathrm{Ca}^{2+}$ wave, with a mean propagation rate of $13.9 \pm 0.4 \mu \mathrm{m} / \mathrm{sec}(n=5)$. Bottom panels in $a$ show a reduction in the stressinduced $\Delta\left[\mathrm{Ca}^{2+}\right]_{i}$ after transfer of cells to a nominally $\mathrm{Ca}^{2+}$-free medium $\left(0 \mathrm{Ca}^{2+}, 0.5\right.$ mM EGTA) for $1 \mathrm{~min}$ or by pretreating cells with $10 \mu \mathrm{M}$ nicardipine for $5 \mathrm{~min}$. High concentrations of ryanodine $(100-200 \mu \mathrm{M})$ reduced $\Delta\left[\mathrm{Ca}^{2+}\right]_{\mathrm{i}}$ and also inhibited $\mathrm{Ca}^{2+}$ wave propagation ( $a$ ), with a $1 \mathrm{hr}$ incubation of cells with $200 \mu \mathrm{M}$ ryanodine resulting in an increase in $\left[\mathrm{Ca}^{2+}\right]_{\mathrm{i}}$ in only the mechanically stressed target cell (arrow). Fluorescence ratio image sequences of $a$ are representative of at least six separate experiments for each treatment. Scale bars, $50 \mu \mathrm{m}$. $b$, $\left[\mathrm{Ca}^{2+}\right]_{\mathrm{i}}$ of up to 25 of the closest responding glial cells to the mechanically stressed target cell was averaged for individual experiments. Traces in $b$ represent the mean of these averaged responses from at least six separate experiments for each of the above treatments, with error bars indicating SD. Similarly, $\Delta\left[\mathrm{Ca}^{2+}\right]_{\mathrm{i}}$ and rate of rise of up to 25 of the closest responding glial cells to the target cell were averaged for individual experiments, with bars in $c$ and $d$ indicating the mean of these averaged parameters \pm SD from at least six separate experiments for each treatment $(* p<0.05$ vs control value; Student's $t$ test for unpaired observations). $e$, Effect of the above treatments on the stress-induced intercellular $\mathrm{Ca}^{2+}$ wave propagation rate. Bars in $e$ indicate the mean $\mathrm{Ca}^{2+}$ wave propagation rate $\pm \mathrm{SD}$ from at least six separate experiments $\left({ }^{*} p<0.05\right.$ vs control value; Student's $t$ test for unpaired observations). $f$, Traces derived from the bottom sequence of ratio images of $a$, showing an increase in $\left[\mathrm{Ca}^{2+}\right]_{\mathrm{i}}$ for cells of zone 2 ; for two cell regions (zone 1 and zone 2) $\sim 100$ $\mu \mathrm{m}$ apart and separated by a void region (bottom sequence of ratio images in $a$ ), mechanical stress of a glial cell in zone 1 (arrow) resulted in an increase in $\left[\mathrm{Ca}^{2+}\right]_{\mathrm{i}}$ in cells located in zone 2 after $\sim 30 \mathrm{sec}$. These data suggest that a messenger or messengers are released from cells in zone 1 after an increase in $\left[\mathrm{Ca}^{2+}\right]_{i}$, and this messenger or messengers diff use across the void region and activate cells located in zone 2 . The arrow in $f$ denotes the time at which the cell in zone 1 was mechanically stimulated and corresponds to $t=0$ sec for the sequence of ratio images in $a$.
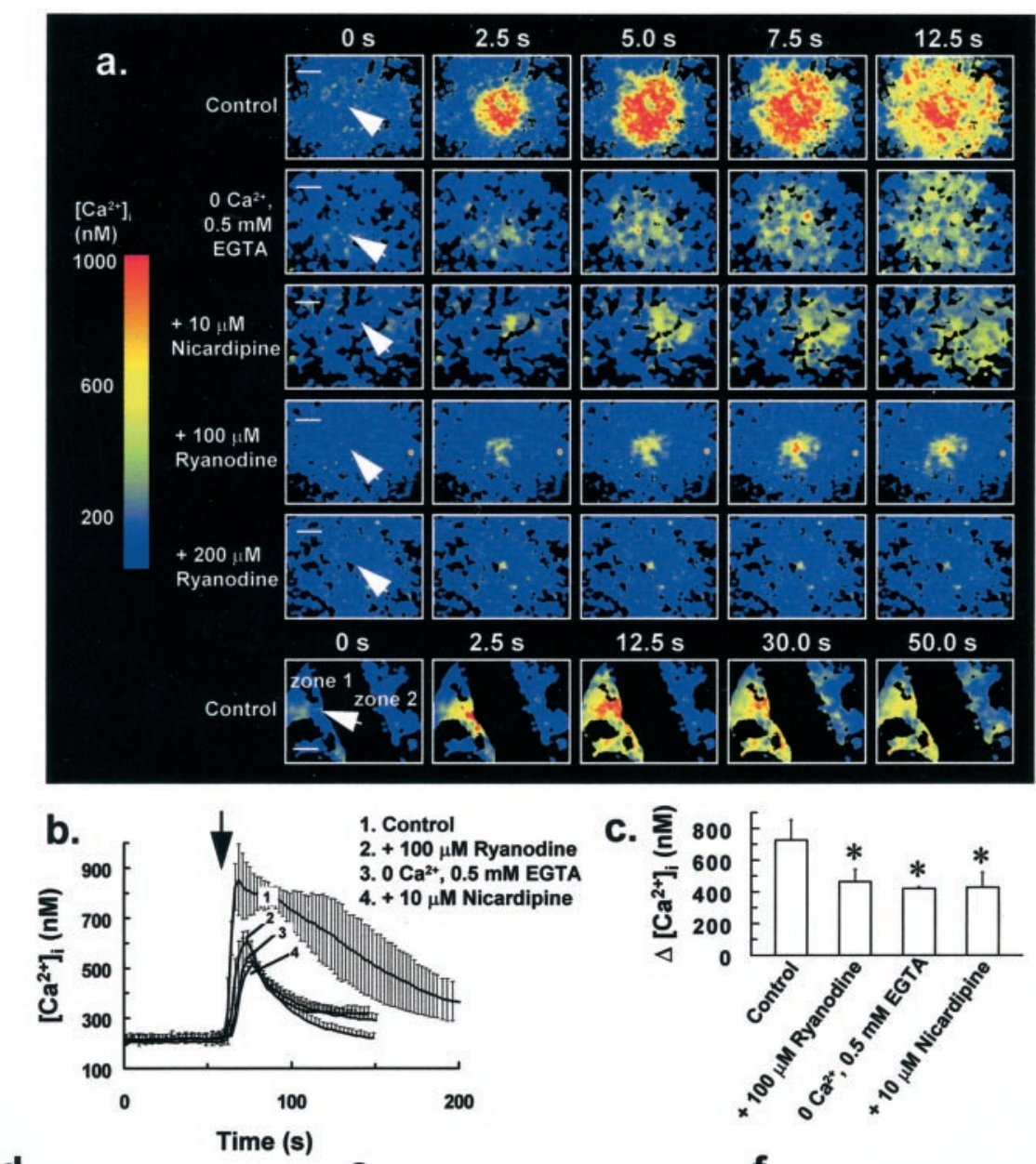

d.
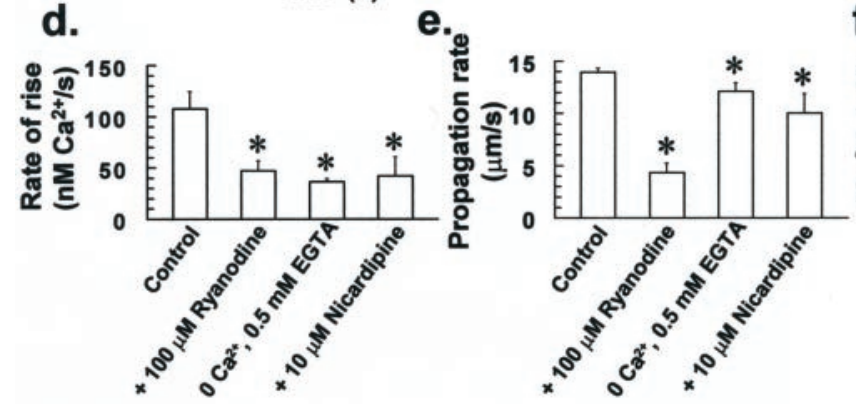

f. 700 Responses in zone 2

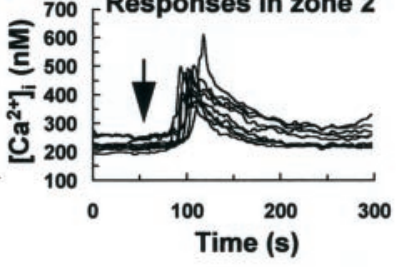

ing cells with $10 \mu \mathrm{M}$ nicardipine (center traces) for $5 \mathrm{~min}$, indicating that both $\mathrm{NO}$ and $\mathrm{Tg}$ activate a $\mathrm{Ca}^{2+}$ influx mechanism in glia. It is noteworthy that a previous study also demonstrated nicardipine sensitivity for $\mathrm{Tg}$-induced $\mathrm{Ca}^{2+}$ influx in immature monocytes (Willmott et al., 1996b). There was no significant additive effect on $\mathrm{Mn}^{2+}$ quench of cytosolic fura-2 fluorescence with a combined application of $\mathrm{NO}$ and $\mathrm{Tg}$, compared to $\mathrm{Tg}$ alone (Fig. 4i). These data suggest that NO acts on the same dihydropyridine-sensitive $\mathrm{Ca}^{2+}$ influx pathway as $\mathrm{Tg}$ in glial cells. Considering that $\mathrm{NO}$ also depletes intracellular $\mathrm{Ca}^{2+}$ stores of glia (see above), it is possible that the nicardipine-sensitive $\mathrm{Ca}^{2+}$ influx activated by $\mathrm{Tg}$ and $\mathrm{NO}$ may be a store-operated $\mathrm{Ca}^{2+}$ influx mechanism or an influx mechanism activated by an increase in $\left[\mathrm{Ca}^{2+}\right]_{\mathrm{i}}$. NO-induced $\mathrm{Ca}^{2+}$ influx in glia may also be via cell depolarization and activation of voltage-gated $\mathrm{Ca}^{2+}$ channels, however it was beyond the scope of this study to test whether NO induces glial cell depolarization.

\section{Intercellular $\mathrm{Ca}^{2+}$ waves induced by mechanical stimulation of single glial cells are inhibited by nicardipine and antagonizing concentrations of ryanodine}

Mechanical stimulation of a single glial cell evoked an intercellular $\mathrm{Ca}^{2+}$ wave, with a mean propagation rate of $13.9 \pm 0.4$ $\mu \mathrm{m} / \mathrm{sec}$ (Fig. 5a,e). This was achieved by slowly lowering a microinjection pipette onto a centrally located, single glial cell. After touching the cell, the pipette was immediately removed. The intercellular wave was characterized by concentric propagation of increased $\left[\mathrm{Ca}^{2+}\right]_{i}$ through neighboring cells. Although initially regarded as being solely attributable to gap junctional 


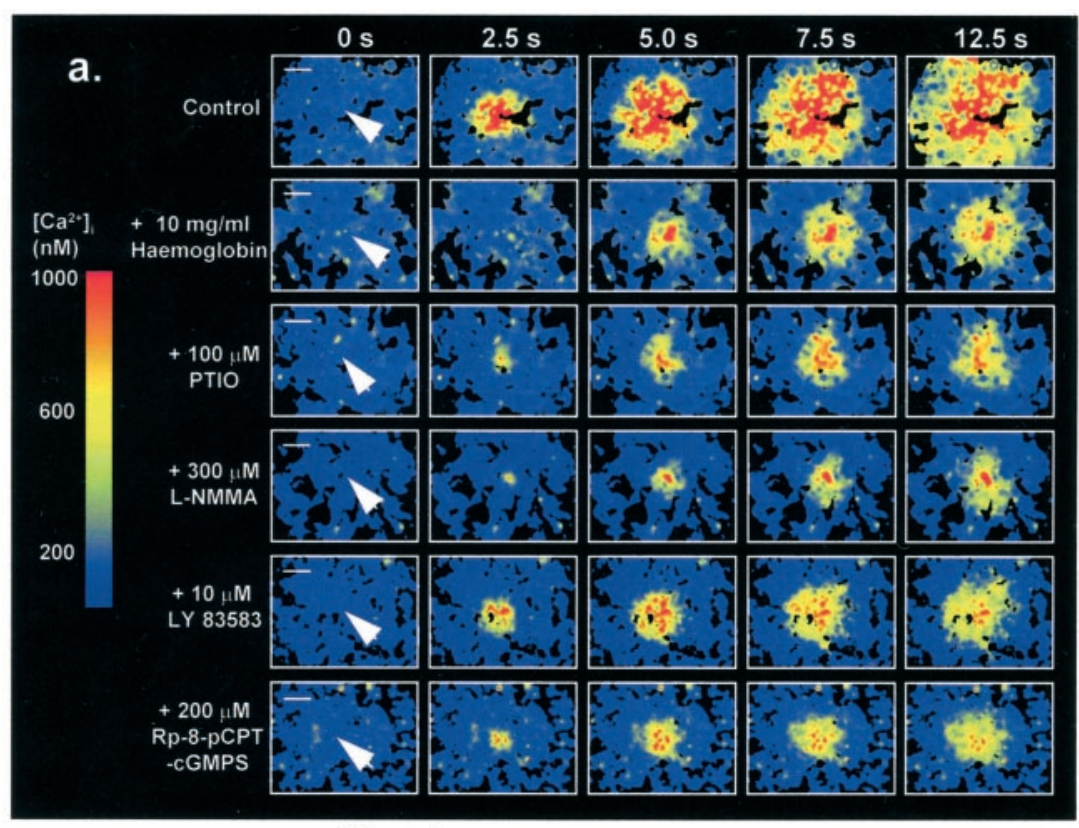

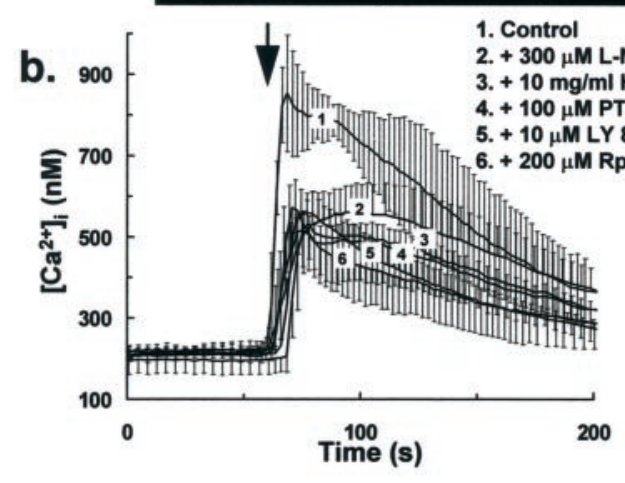

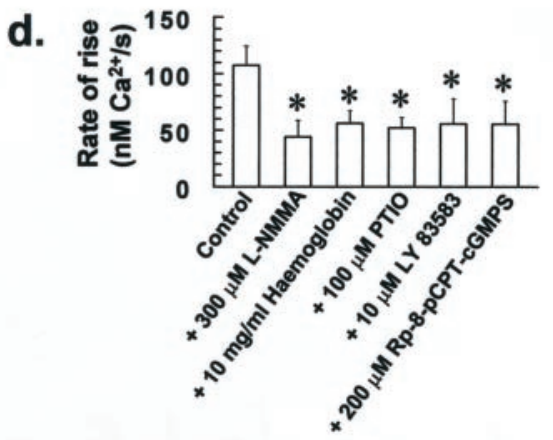

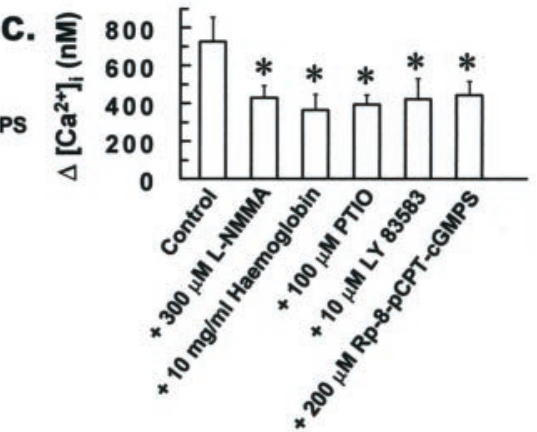

e.

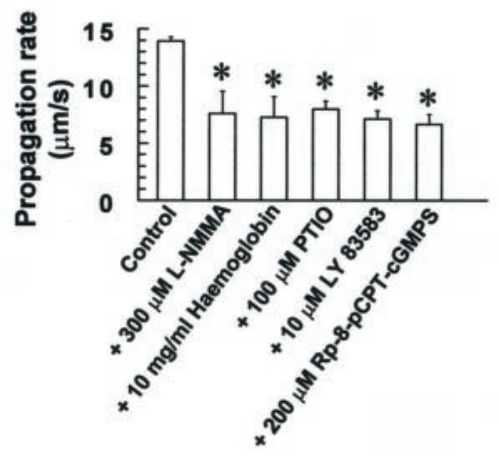

Figure 6. Antagonists of NO-Gkinase signaling inhibit intercellular $\mathrm{Ca}^{2+}$ wave propagation in glia. $a$, Pretreating cells with NO scavengers or inhibitors of the NO-G-kinase signaling pathway $(10 \mathrm{mg} / \mathrm{ml}$ hemoglobin for 5 min, $100 \mu \mathrm{M}$ PTIO for $5 \mathrm{~min}, 300 \mu \mathrm{M}$ L-NMMA for $30 \mathrm{~min}, 10 \mu \mathrm{M}$ LY 83583 for $1 \mathrm{~min}$, or $200 \mu \mathrm{M} \mathrm{Rp}-8$-pCPTcGMPS for $30 \mathrm{~min}$ ) resulted in a reduction in both $\Delta\left[\mathrm{Ca}^{2+}\right]_{i}$ and also $\mathrm{Ca}^{2+}$ wave propagation rate after mechanical stress of single glial cells (arrow). Fluorescence ratio image sequences in $a$ are representative of at least six separate experiments for each treatment. Scale bars, $50 \mu \mathrm{m} . b$, $\left[\mathrm{Ca}^{2+}\right]_{\mathrm{i}}$ for 25 of the closest responding glial cells to the mechanically stressed target cell was averaged for individual experiments. Traces in $b$ represent the mean of these averaged responses from at least six separate experiments for each of the above treatments, with error bars indicating SD. Similarly, $\Delta\left[\mathrm{Ca}^{2+}\right]_{\mathrm{i}}$ and rate of rise of $\left[\mathrm{Ca}^{2+}\right]_{\mathrm{i}}$ for 25 of the closest responding glial cells to the mechanically stressed target cell were averaged for individual experiments, with bars in $c$ and $d$ representing the mean of these averaged parameters \pm SD from at least six separate experiments $\left({ }^{*} p<0.05\right.$ vs control value; Student's $t$ test for unpaired observations). $e$, Effect of the above treatments on the stress-induced intercellular $\mathrm{Ca}^{2+}$ wave propagation rate. Bars in $e$ represent the mean $\mathrm{Ca}^{2+}$ wave propagation rate \pm SD from at least six separate experiments $\left({ }^{*} p<0.05\right.$ vs control value; Student's $t$ test for unpaired observations). communication between cells, there is increasing evidence that extracellular $\mathrm{Ca}^{2+}$ signaling might also play a role in intercellular $\mathrm{Ca}^{2+}$ waves in glia (Charles, 1998; Cotrina et al., 1998; Guthrie et al., 1999). Indeed in this study, we observed increases in $\left[\mathrm{Ca}^{2+}\right]_{\mathrm{i}}$ (Fig. $5 f$ ) of cells separated from the mechanically stressed target cell region by a void region (Fig. $5 a$, bottom sequence of ratio images), suggesting the release of a freely diffusible messenger and an extracellular, gap junction-independent mode of communication for this response.

The incubation of cells in a nominally $\mathrm{Ca}^{2+}$-free medium $(0$ $\mathrm{Ca}^{2+}, 0.5 \mathrm{~mm}$ EGTA) for $1 \mathrm{~min}$ or pretreating cells with $10 \mu \mathrm{M}$ nicardipine for $5 \mathrm{~min}$ resulted in a significant reduction in both the stress-induced $\Delta\left[\mathrm{Ca}^{2+}\right]_{i}$ (Fig. $5 a-c$ ) and rate of rise for increases in $\left[\mathrm{Ca}^{2+}\right]_{\mathrm{i}}$ of individual cells (Fig. $5 d$ ). Intercellular
$\mathrm{Ca}^{2+}$ wave propagation rate was also slowed by a small, but significant amount by these treatments (Fig. 5e). Similarly, high concentrations of ryanodine $(100-200 \mu \mathrm{M})$ reduced $\Delta\left[\mathrm{Ca}^{2+}\right]_{\mathrm{i}}$ (Fig. $5 a-c$ ), rate of rise of increases in $\left[\mathrm{Ca}^{2+}\right]_{\mathrm{i}}$ (Fig. $5 d$ ), and also $\mathrm{Ca}^{2+}$ wave propagation rate (Fig. $5 e$ ), with a $1 \mathrm{hr}$ incubation of cells with $200 \mu \mathrm{M}$ ryanodine resulting in an increase in $\left[\mathrm{Ca}^{2+}\right]_{\mathrm{i}}$ in only the mechanically stimulated target cell (Fig. $5 a$ ). As for the NO puff experiments, treatment of cells with this concentration of ryanodine did not result in $\mathrm{Ca}^{2+}$ store depletion over the course of drug preincubation. These data suggest that both $\mathrm{Ca}^{2+}$ mobilization and $\mathrm{Ca}^{2+}$ influx, which is nicardipine-sensitive, contribute to stress-induced intercellular $\mathrm{Ca}^{2+}$ waves in glia, with $\mathrm{Ca}^{2+}$ release from a RyR-linked $\mathrm{Ca}^{2+}$ store contributing to the mobilization component. It is therefore noteworthy that the phar- 


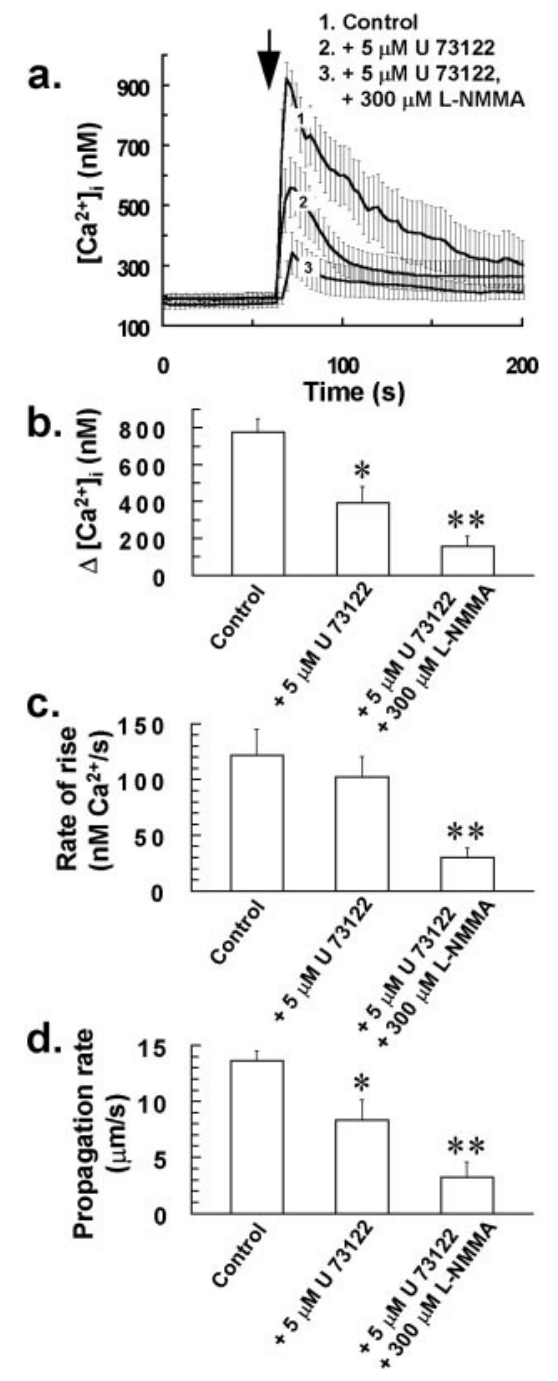

Figure 7. Additive inhibitory effect for PLC and nitric oxide synthase inhibitors on intercellular $\mathrm{Ca}^{2+}$ wave propagation in glia. Pretreating cells with the phospholipase $\mathrm{C}$ inhibitor U $73122(5 \mu \mathrm{M})$ for $10 \mathrm{~min}$ or L-NMMA $(300 \mu \mathrm{M})$ for $30 \mathrm{~min}$ and $\mathrm{U} 73122(5 \mu \mathrm{M})$ for $10 \mathrm{~min}$ in combination, resulted in a reduction in both $\Delta\left[\mathrm{Ca}^{2+}\right]_{\mathrm{i}}(b)$ and also $\mathrm{Ca}^{2+}$ wave propagation rate $(d)$ after mechanical stress of a single glial cell at the time indicated by the arrow in $a$, with the combined drug treatment having a greater inhibitory effect on the $\mathrm{Ca}^{2+}$ wave compared to solely treating cells with PLC inhibitor. $a,\left[\mathrm{Ca}^{2+}\right]_{\mathrm{i}}$ for 25 of the closest responding glial cells to the mechanically stressed target cell was averaged for individual experiments. Traces in $a$ represent the mean of these averaged responses from at least four separate experiments for each of the above treatments, with error bars indicating SD. Similarly, $\Delta\left[\mathrm{Ca}^{2+}\right]_{\mathrm{i}}$ and rate of rise of $\left[\mathrm{Ca}^{2+}\right]_{\mathrm{i}}$ for 25 of the closest responding glial cells to the mechanically stressed target cell were averaged for individual experiments, with bars in $b$ and $c$ indicating the mean of these averaged parameters $\pm \mathrm{SD}$ from at least four separate experiments $\left({ }^{*} p<0.05\right.$ vs control value; ${ }^{*} p<$ 0.05 vs $5 \mu \mathrm{M}$ U 73122 value; Student's $t$ test for unpaired observations). $d$, Effect of the above treatments on the stress-induced intercellular $\mathrm{Ca}^{2+}$ wave propagation rate. Bars in $d$ indicate the mean $\mathrm{Ca}^{2+}$ wave propagation rate $\pm \mathrm{SD}$ from at least four separate experiments $\left({ }^{*} p<0.05\right.$ vs control value; ${ }^{* *} p<0.05$ vs $5 \mu \mathrm{M}$ U 73122 value; Student's $t$ test for unpaired observations).

macology of the stress-induced intercellular $\mathrm{Ca}^{2+}$ wave shares similarity with the NO-induced increase in $\left[\mathrm{Ca}^{2+}\right]_{\mathrm{i}}$, thus suggesting a possible role for the $\mathrm{NO}-\mathrm{G}$-kinase signaling pathway in this particular response.

From the data of Figure 5, it may seem unlikely that the propagation rate of the stress-induced $\mathrm{Ca}^{2+}$ wave is dependent on $\Delta\left[\mathrm{Ca}^{2+}\right]_{\mathrm{i}}$ of individual cells, because although there was no significant difference in $\Delta\left[\mathrm{Ca}^{2+}\right]_{\mathrm{i}}$ for the stress response of cells bathed in a nominally $\mathrm{Ca}^{2+}$-free medium or for cells treated with $100 \mu \mathrm{M}$ ryanodine or $10 \mu \mathrm{M}$ nicardipine (Fig. $5 c$ ), the propagation rate of the $\mathrm{Ca}^{2+}$ wave for ryanodine-treated cells (Fig. 5e) was reduced compared to the other treatments $(p<0.05$; Student's $t$ test for unpaired observations).

\section{Intercellular $\mathrm{Ca}^{2+}$ waves induced by mechanical stimulation of single glial cells are inhibited by antagonists of the NO-G-kinase signaling pathway and phospholipase $\mathbf{C}$ inhibition}

Pretreating cells with inhibitors of the NO-G-kinase signaling pathway (100 $\mu \mathrm{M}$ PTIO for $5 \mathrm{~min}, 10 \mathrm{mg} / \mathrm{ml}$ hemoglobin for 5 min, $300 \mu \mathrm{M} \mathrm{L}-\mathrm{NMMA}$ for $30 \mathrm{~min}, 10 \mu \mathrm{M}$ LY 83583 for $1 \mathrm{~min}$, or $200 \mu \mathrm{M}$ Rp-8-pCPT-cGMPS for $30 \mathrm{~min}$ ) resulted in a significant reduction in $\Delta\left[\mathrm{Ca}^{2+}\right]_{\mathrm{i}}$ (Fig. $6 a-c$ ), rate of rise of increases in $\left[\mathrm{Ca}^{2+}\right]_{\mathrm{i}}$ of individual cells (Fig. $6 d$ ), and also $\mathrm{Ca}^{2+}$ wave propagation rate (Fig. 6e) after mechanical stimulation of single glial cells, as above. The extent of intercellular $\mathrm{Ca}^{2+}$ wave propagation was also affected by these treatments, with waves usually restricted to coverslip areas of between 1 and $2 \times 10^{4} \mu \mathrm{m}^{2}$, as opposed to 5 and $6 \times 10^{4} \mu \mathrm{m}^{2}$ for untreated control cells. These agents alone had no effect on $\left[\mathrm{Ca}^{2+}\right]_{\mathrm{i}}$ and did not cause $\mathrm{Ca}^{2+}$ store depletion during the preincubation period. Furthermore, it is unlikely that $\mathrm{Ca}^{2+}$ wave inhibition was caused by some rundown phenomenon, because incubating cells in the absence of drugs for up to $2 \mathrm{hr}$ at $22^{\circ} \mathrm{C}$ did not significantly affect stressinduced intercellular $\mathrm{Ca}^{2+}$ wave parameters.

The above agents reduced each of the measured $\mathrm{Ca}^{2+}$ response parameters by $\sim 50 \%$ (Fig. $6 c-e$ ), suggesting that $\mathrm{Ca}^{2+}$ mobilization and influx induced by the NO-G-kinase signaling pathway are fundamental components of stress-induced intercellular $\mathrm{Ca}^{2+}$ waves in glial cells. Because the extracellular NO scavenger hemoglobin $(10 \mathrm{mg} / \mathrm{ml})$ was also effective in inhibiting intercellular $\mathrm{Ca}^{2+}$ waves induced by mechanical stress (Fig. 6), it is likely that NO acts as an extracellular messenger in this response, freely diffusing between adjacent cells, and thereby assisting intercellular $\mathrm{Ca}^{2+}$ wave propagation.

Pretreating cells with the phospholipase C inhibitor U 73122 (5 $\mu \mathrm{M})$ for $10 \mathrm{~min}$ or L-NMMA $(300 \mu \mathrm{M})$ for $30 \mathrm{~min}$ and $\mathrm{U} 73122(5$ $\mu \mathrm{M}$ ) for $10 \mathrm{~min}$ in combination, resulted in a reduction in both $\Delta\left[\mathrm{Ca}^{2+}\right]_{\mathrm{i}}$ (Fig. $\left.7 a, b\right)$, rate of rise of increases in $\left[\mathrm{Ca}^{2+}\right]_{\mathrm{i}}$ of individual glial cells for the combined drug treatment (Fig. 7c) and also intercellular $\mathrm{Ca}^{2+}$ wave propagation rate (Fig. $7 d$ ) after mechanical stress of a single glial cell. For the combined drug treatment, there was a greater reduction in $\Delta\left[\mathrm{Ca}^{2+}\right]_{\mathrm{i}}$ and propagation rate of the $\mathrm{Ca}^{2+}$ wave $(p<0.05$; Student's $t$ test for unpaired observations) compared to parameters derived from cells that had been treated solely with phospholipase C (PLC) inhibitor for $10 \mathrm{~min}$ (Fig. 7) or $300 \mu \mathrm{M} \mathrm{L}-\mathrm{NMMA}$ for $30 \mathrm{~min}$ (Fig. 6) before mechanical stress. This additive inhibitory effect for PLC and nitric oxide synthase inhibitors on the intercellular $\mathrm{Ca}^{2+}$ wave suggests that both $\mathrm{IP}_{3}$ and $\mathrm{NO}$-induced $\mathrm{Ca}^{2+}$ mobilization contribute to the stress-induced $\mathrm{Ca}^{2+}$ response of glia.

\section{Increased NO production in glia after mechanical stress of a single glial cell}

Further evidence for the participation of NO in stress-induced intercellular $\mathrm{Ca}^{2+}$ waves was derived from experiments using the fluorescent NO probe DAF-2. In these experiments we observed 

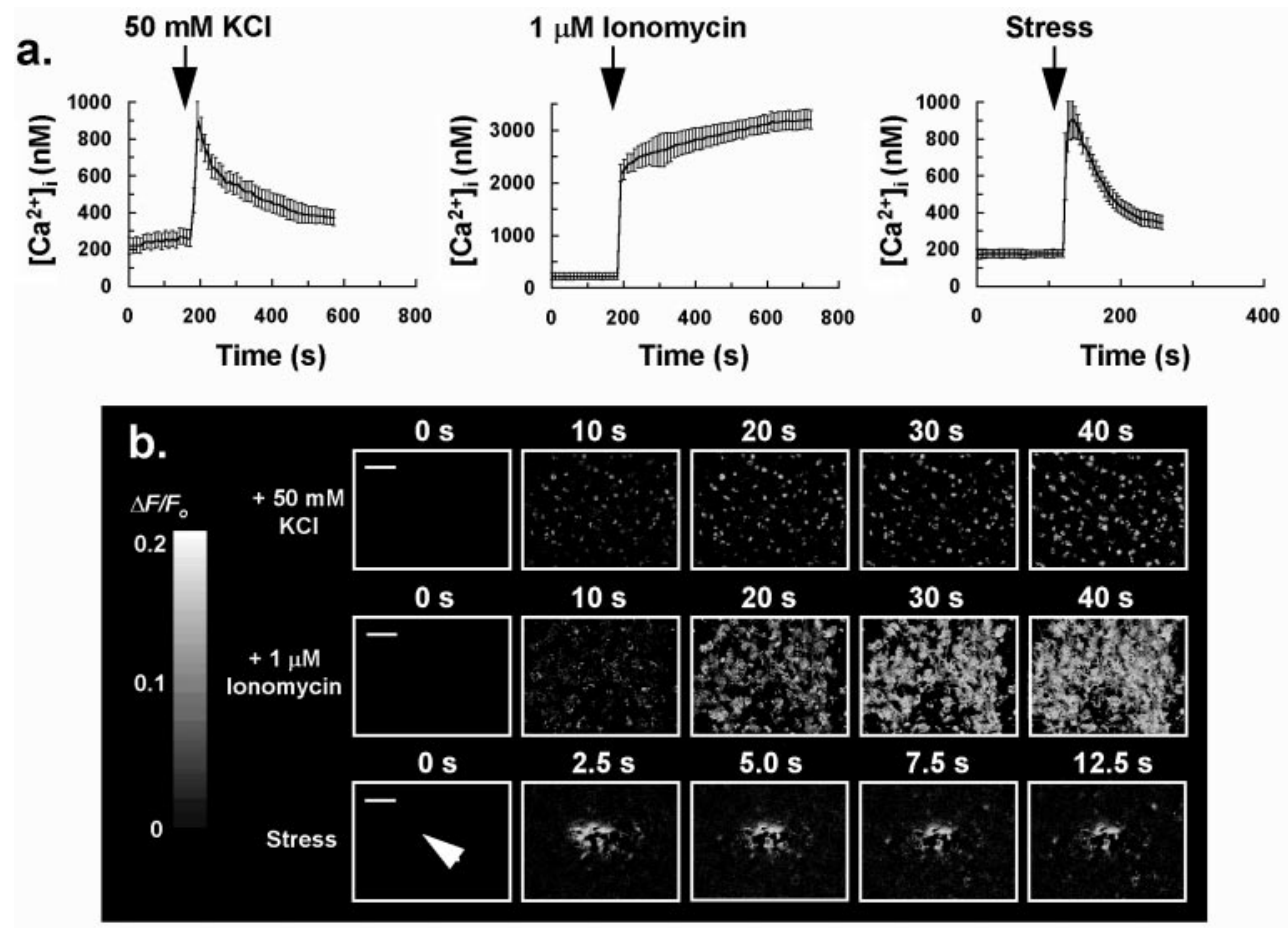
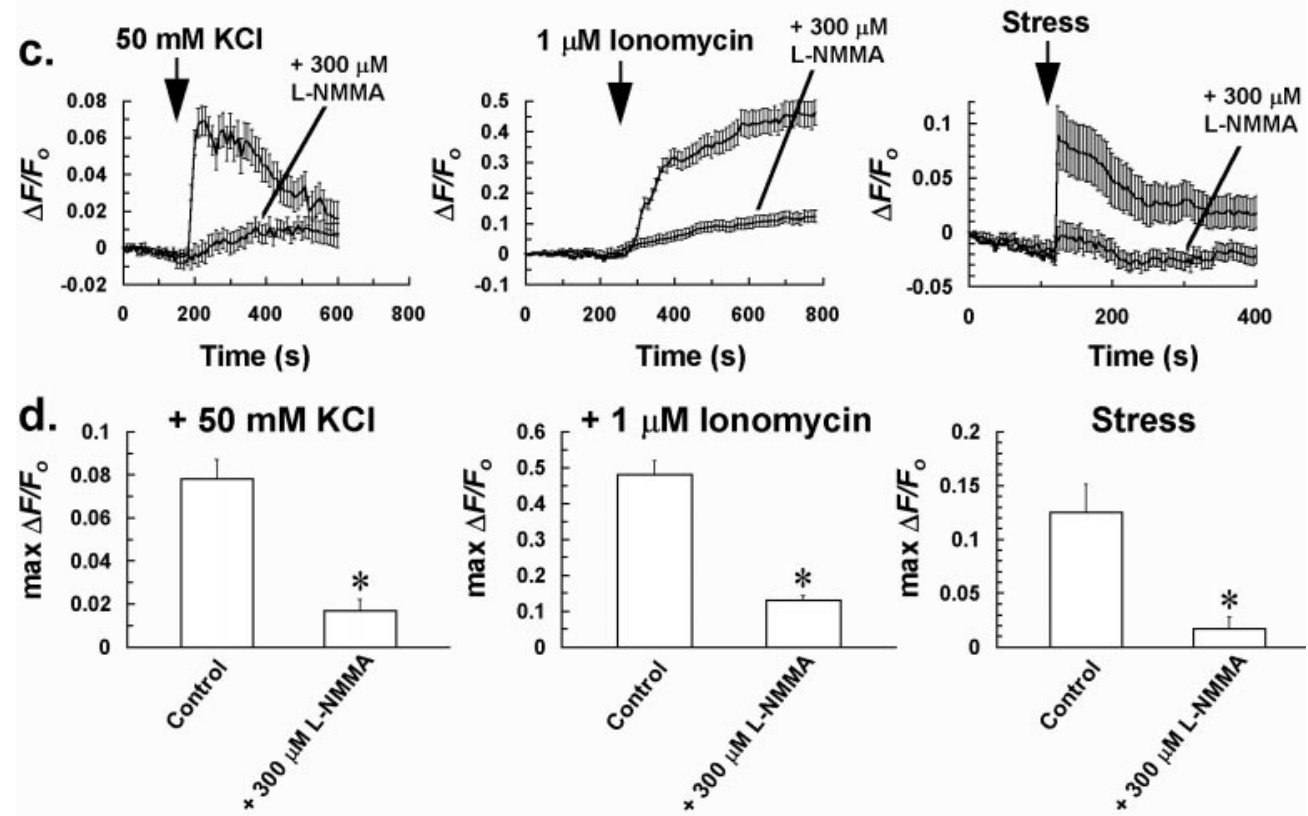

Figure 8. Evidence that mechanical stress and treatments that induce an increase in $\left[\mathrm{Ca}^{2+}\right]_{\mathrm{i}}$ independently of cell surface receptor activation are coupled to an increase in NO production in glia. $a$, Increase in $\left[\mathrm{Ca}^{2+}\right]_{\mathrm{i}}$ of glial cells to $50 \mathrm{~mm} \mathrm{KCl}, 1 \mu \mathrm{M}$ ionomycin, or mechanical stress of a single glial cell. $\left[\mathrm{Ca}^{2+}\right]_{i}$ of at least $25 \mathrm{re}-$ sponding glial cells (for the stress response, chosen cells were the closest to the mechanically stressed target cell) was averaged for individual experiments. Traces in $a$ represent the mean of these averaged responses from at least four separate experiments for each of the above treatments, with error bars indicating SD. $b$, Sequences of ratio images $\left(\Delta F / F_{\mathrm{o}}\right)$ showing an increase in DAF-2 fluorescence in cells after bolus addition of $50 \mathrm{~mm} \mathrm{KCl}$ or 1 $\mu \mathrm{M}$ ionomycin to the incubation bath, or mechanical stress of a single glial cell (arrow) at $t=0 \mathrm{sec}$, indicating that these treatments induce an increase in cytosolic NO in cells. Fluorescence ratio image sequences of $b$ are representative of at least four separate experiments for each of the above treatments. Scale bars, $50 \mu \mathrm{m} . c, \Delta F / F_{\mathrm{o}}$ of at least 25 glial cells (for the stress response, chosen cells were the closest to the mechanically stressed target cell) was averaged for individual experiments of $b$. Traces in $c$ represent the mean of these averaged responses from at least four separate experiments for each of the above treatments, with error bars indicating SD. Pretreatment of cells for $30 \mathrm{~min}$ with L-NMMA inhibited the rise in cytosolic NO to the above treatments $(c$, $d) . d$, Graphs derived from the experiments of $c$, showing a reduction in $\mathrm{NO}$ production to $50 \mathrm{mM} \mathrm{KCl}, 1 \mu \mathrm{M}$ ionomycin, and mechanical stress of a single glial cell, after pretreatment of cells with $300 \mu \mathrm{M}$ L-NMMA for $30 \mathrm{~min}$. The maximum $\Delta F / F_{\mathrm{o}}$ value of at least 25 glial cells (for the stress response, chosen cells were the closest to the mechanically stressed target cell) was averaged for individual experiments, with bars in $d$ representing the mean of these averaged parameters \pm SD from at least four separate experiments $\left({ }^{*} p<0.05\right.$ vs control value). an increase in DAF-2 fluorescence (490 nm excitation) in cells (Fig. $8 b-d$ ) after treatments that induce an increase in $\left[\mathrm{Ca}^{2+}\right]_{\mathrm{i}}$ presumably independently of cell surface receptor activation (Fig. $8 a$ ); these included mechanical stress of a single glial cell, depolarizing cells with $50 \mathrm{~mm} \mathrm{KCl}$, and application of $1 \mu \mathrm{M}$ of the $\mathrm{Ca}^{2+}$ ionophore ionomycin to cells. Increases in intracellular DAF-2 fluorescence to these treatments were abrogated by pretreating cells with $300 \mu \mathrm{M}$ L-NMMA for 30 min (Fig. 8c,d), indicating that they were caused by nitric oxide synthase activity and an increase in cytosolic NO. It is especially noteworthy that the profile and time scale of NO responses (Fig. $8 c$ ) were similar to the $\mathrm{Ca}^{2+}$ responses (Fig. $8 a$ ) induced by the above treatments, possibly suggesting a close coupling between $\left[\mathrm{Ca}^{2+}\right]_{\mathrm{i}}$ and cytosolic NO concentration in cells, and seemingly consistent with a previous study suggesting the presence of $\mathrm{Ca}^{2+}$-dependent nitric oxide synthase in glia (Feinstein et al., 1994). It is also noteworthy that the NO response after mechanical stress of a single glial cell (Fig. $8 b$ ) shares similar spatiotemporal characteristics as the stress-induced intercellular $\mathrm{Ca}^{2+}$ wave (Figs. $5 a, 6 a$ ), with cytosolic NO increasing initially in cells close to the target cell, followed by increases in more distant cells after $12.5 \mathrm{sec}$.

\section{The increase in $\left[\mathrm{Ca}^{2+}\right]_{i}$ induced by ATP is not mediated via an increased production of NO in glial cells and is not dependent on ryanodine receptor- linked $\mathrm{Ca}^{2+}$ release}

To test whether NO-induced $\mathrm{Ca}^{2+}$ mobilization from ryanodine receptor-linked $\mathrm{Ca}^{2+}$ stores might also contribute to a cell sur- 
Figure 9. $\mathrm{P}_{2}$-receptor activation is not coupled to an increased production of $\mathrm{NO}$ in glial cells, and the associated $\mathrm{Ca}^{2+}$ response is not dependent on ryanodine receptor-linked $\mathrm{Ca}^{2+}$ release. $a$, Effect of pretreating mixed glial-neuron cultures with $200 \mu \mathrm{M}$ ryanodine for $1 \mathrm{hr}, 300 \mu \mathrm{M} \mathrm{L}-\mathrm{NMMA}$ for $30 \mathrm{~min}$, or $5 \mu \mathrm{M} \mathrm{U} 73122$ for $10 \mathrm{~min}$ on the increase in $\left[\mathrm{Ca}^{2+}\right]_{\mathrm{i}}$ induced by bolus application of $10 \mu \mathrm{M}$ ATP to the incubation bath. $\left[\mathrm{Ca}^{2+}\right]_{\mathrm{i}}$ for at least 50 responding glial cells was averaged for individual experiments. Traces in $a$ represent the mean of these averaged responses from at least four separate experiments for each of the above treatments, with error bars indicating SD. Similarly, $\Delta\left[\mathrm{Ca}^{2+}\right]_{\mathrm{i}}$ and rate of rise of $\left[\mathrm{Ca}^{2+}\right]_{\mathrm{i}}$ for at least 50 responding glial cells were averaged for individual experiments, with bars in $b$ and $c$ representing the mean of these averaged parameters $\pm \mathrm{SD}$ from at least four separate experiments. $d$, Percentage of cells in a $350 \times 300 \mu \mathrm{m}$ field that demonstrated a rise in $\left[\mathrm{Ca}^{2+}\right]_{\mathrm{i}}$ to 10 $\mu \mathrm{M}$ ATP, after pretreatment with the above drugs. Bars in $d$ are mean values \pm SD from at least four separate experiments $\left({ }^{*} p<0.05\right.$ vs control value; Student's $t$ test for unpaired observations). $e$, Decrease in DAF-2 fluorescence in glial cells after application of $10 \mu \mathrm{M}$ ATP to the incubation bath. $\Delta F / F_{\text {o }}$ of at least 50 glial cells was averaged for individual experiments, with the trace in $e$ representing the mean of these averaged responses from at least four separate experiments, with error bars indicating SD.

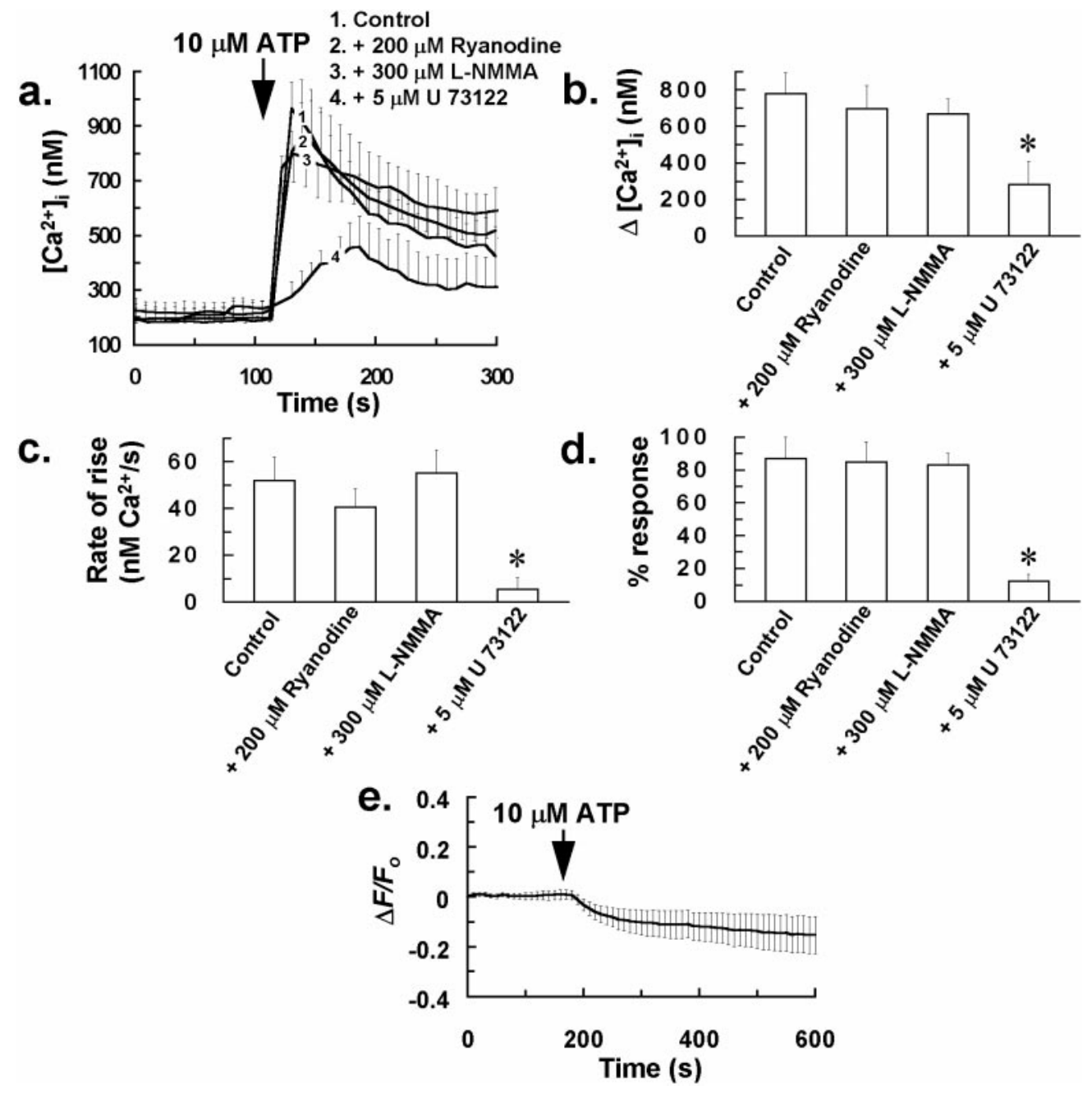

face receptor-linked $\mathrm{Ca}^{2+}$ response that has been proposed to be mediated via the G-protein-coupled activation of PLC and $\mathrm{IP}_{3}$ generation in astrocytes (Centemeri et al., 1997), we examined the effect of an antagonizing concentration of ryanodine $(200 \mu \mathrm{M})$ and L-NMMA $(300 \mu \mathrm{M})$ on the increase in $\left[\mathrm{Ca}^{2+}\right]_{\mathrm{i}}$ induced by the $\mathrm{P}_{2}$-receptor agonist ATP. This species has been previously proposed as a candidate for the extracellular messenger involved in mediating intercellular $\mathrm{Ca}^{2+}$ waves in glia (Cotrina et al., 1998; Guthrie et al., 1999). In direct contrast to their inhibitory effect on the intercellular $\mathrm{Ca}^{2+}$ wave induced by mechanical stress, the above treatments did not significantly affect the increase in $\left[\mathrm{Ca}^{2+}\right]_{\mathrm{i}}$ induced by bolus application of $10 \mu \mathrm{M}$ ATP to cells (Fig. $9 a-d)$. However, consistent with the study of Centemeri et al. (1997), we did observe significant inhibition of the ATP-induced $\mathrm{Ca}^{2+}$ response after pretreatment of glial cells with $5 \mu \mathrm{M}$ of the PLC inhibitor U 73122 (Fig. 9a-d), suggesting that this response is dependent on intracellular $\mathrm{IP}_{3}$ generation and independent of cytosolic NO or RyR-linked $\mathrm{Ca}^{2+}$ release. Further evidence for this notion was derived from experiments with the NO probe DAF-2, in which no increase in DAF-2 fluorescence was observed in any glial cells after administration of $10 \mu \mathrm{M}$ ATP (Fig. 9e). The absence of any rise in cytosolic NO in response to ATP might explain the apparent lack of RyR-linked $\mathrm{Ca}^{2+}$ release for the above response.
The $P_{2}$ receptor antagonist suramin and the ATPdegrading enzyme apyrase do not completely block stress-induced intercellular $\mathrm{Ca}^{2+}$ waves of glia

Pretreating cells with the general $\mathrm{P}_{2}$ receptor antagonist suramin $(100 \mu \mathrm{M})$ or the ATP-degrading enzyme apyrase $(40 \mathrm{U} / \mathrm{ml}$; apyrase grade III; Sigma) for $30 \mathrm{~min}$ resulted in a reduction in both $\Delta\left[\mathrm{Ca}^{2+}\right]_{\mathrm{i}}$ and also $\mathrm{Ca}^{2+}$ wave propagation rate, after mechanical stress of a single glial cell (Fig. 10). As for antagonists of NO-G-kinase signaling, the extent of intercellular $\mathrm{Ca}^{2+}$ wave propagation was also affected by pretreating cells with suramin or apyrase, with waves usually restricted to coverslip areas of between 1 and $3 \times 10^{4} \mu^{2}$ (involving 15-40 cells), as opposed to coverslip areas of 5 and $6 \times 10^{4} \mu \mathrm{m}^{2}$ (involving $>180$ cells) for untreated control cells. These data are essentially similar to the previous observations of Cotrina et al. (1998), who also demonstrated inhibition, but not complete abrogation of the stressinduced intercellular $\mathrm{Ca}^{2+}$ wave by suramin and apyrase. This suggests that although ATP release from glia appears to play a role in $\mathrm{Ca}^{2+}$ wave propagation, one or more other underlying mechanisms are also likely to contribute to the stress-induced wave.

\section{DISCUSSION}

Results from this study suggest that NO-G-kinase signaling is coupled to $\mathrm{Ca}^{2+}$ mobilization and influx in glial cells and that this 


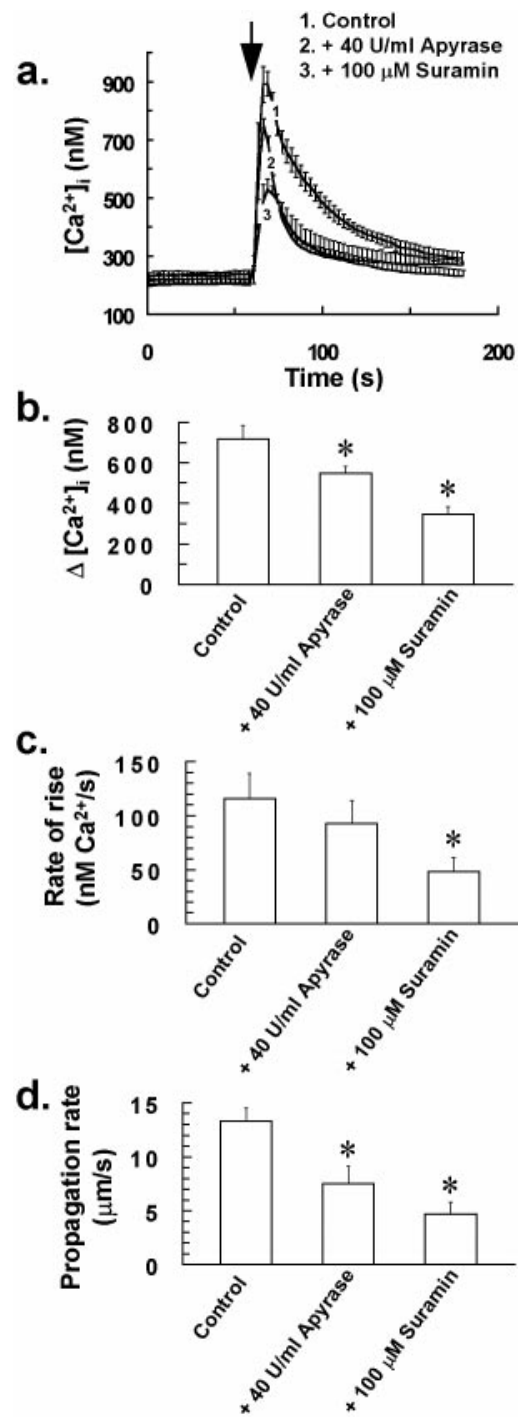

Figure 10. The $\mathrm{P}_{2}$ receptor antagonist suramin and the ATP-degrading enzyme apyrase inhibit the stress-induced intercellular $\mathrm{Ca}^{2+}$ wave of glia. Pretreating cells with the general $\mathrm{P}_{2}$ receptor antagonist suramin (100 $\mu \mathrm{M})$ or the ATP-degrading enzyme apyrase $(40 \mathrm{U} / \mathrm{ml})$ for $30 \mathrm{~min}$ resulted in a reduction in both $\Delta\left[\mathrm{Ca}^{2+}\right]_{\mathrm{i}}(a, b)$ and $\mathrm{Ca}^{2+}$ wave propagation rate $(d)$ after mechanical stress of a single glial cell at the time indicated by the arrow in $a . a,\left[\mathrm{Ca}^{2+}\right]_{\mathrm{i}}$ for 15 of the closest responding glial cells to the mechanically stressed target cell was averaged for individual experiments. Traces in $a$ represent the mean of these averaged responses from at least four separate experiments for each of the above treatments, with error bars indicating SD. Similarly, $\Delta\left[\mathrm{Ca}^{2+}\right]_{i}$ and rate of rise of $\left[\mathrm{Ca}^{2+}\right]_{i}$ for 15 of the closest responding glial cells to the mechanically stressed target cell were averaged for individual experiments, with bars in $b$ and $c$ indicating the mean of these averaged parameters \pm SD from at least four separate experiments $\left({ }^{*} p<0.05\right.$ vs control value; Student's $t$ test for unpaired observations). $d$, Effect of the above treatments on the stress-induced intercellular $\mathrm{Ca}^{2+}$ wave propagation rate. Bars in $d$ indicate the mean $\mathrm{Ca}^{2+}$ wave propagation rate $\pm \mathrm{SD}$ from at least four separate experiments ( ${ }^{*} p<0.05$ vs control value; Student's $t$ test for unpaired observations). The extent of intercellular $\mathrm{Ca}^{2+}$ wave propagation was also affected by pretreating cells with suramin or apyrase, with waves usually restricted to coverslip areas of between 1 and $3 \times 10^{4} \mu \mathrm{m}^{2}$, as opposed to 5 and $6 \times 10^{4} \mu \mathrm{m}^{2}$ for untreated control cells.

pathway plays a fundamental role in mediating intercellular $\mathrm{Ca}^{2+}$ waves induced by mechanical stimulation of single cells. To our knowledge, this is the first study to highlight a role for the NO-G-kinase signaling pathway and RyR-linked $\mathrm{Ca}^{2+}$ release in intercellular $\mathrm{Ca}^{2+}$ wave generation and propagation in glia. A previous study suggested the presence of RyR-coupled $\mathrm{Ca}^{2+}$ pools in astrocytes, because a low, agonizing concentration of ryanodine $(10 \mu \mathrm{M})$ induced $\mathrm{Ca}^{2+}$ store depletion in these cells (Giaume and Venance, 1998). However, the effect on intercellular $\mathrm{Ca}^{2+}$ waves of higher, antagonizing ryanodine concentrations, which are known to block the associated $\mathrm{Ca}^{2+}$ conductance of RyRs (Rousseau et al., 1987; Zimanyi et al., 1992), was not assessed by Giaume and Venance (1998).

In our study, we demonstrate that a high concentration of ryanodine $(200 \mu \mathrm{M})$ is effective in completely blocking the intercellular $\mathrm{Ca}^{2+}$ wave induced by mechanical stress of a single glial cell. This result appears to conflict with data from previous studies that demonstrated abrogation of the stress-induced $\mathrm{Ca}^{2+}$ wave by the $\mathrm{IP}_{3}$ receptor $\left(\mathrm{IP}_{3} \mathrm{R}\right)$ antagonist heparin in retinal glial cells (Newman and Zahs, 1997) and also by the PLC inhibitor U 73122 in astrocytes (Charles et al., 1993; Venance et al., 1997), suggesting that the response was mediated principally by $\mathrm{IP}_{3}$-induced $\mathrm{Ca}^{2+}$ release from $\mathrm{IP}_{3} \mathrm{R}$-linked $\mathrm{Ca}^{2+}$ stores. However, it is possible that both $\mathrm{IP}_{3} \mathrm{Rs}$ and RyRs are required in an activated, conducting state to allow the generation and propagation of the $\mathrm{Ca}^{2+}$ wave. For example, $\mathrm{IP}_{3} \mathrm{R}$-linked $\mathrm{Ca}^{2+}$ release may be required to prime and activate RyR-linked $\mathrm{Ca}^{2+}$ release, possibly via NO production, with the latter mechanism perhaps contributing principally to the propagation of the $\mathrm{Ca}^{2+}$ wave. Although the precise reason for the complete sensitivity of the stress-induced $\mathrm{Ca}^{2+}$ wave to either RyR or $\mathrm{IP}_{3} \mathrm{R} / \mathrm{PLC}$ inhibition is not apparent from our study, it nevertheless remains likely that both $\mathrm{IP}_{3}$ and $\mathrm{NO}$-induced $\mathrm{Ca}^{2+}$ release mechanisms contribute to the overall response, because a combined treatment of cells with PLC and NOS inhibitors had an additive inhibitory effect on the $\mathrm{Ca}^{2+}$ wave (Fig. 7). It has previously been reported that treatment of glial cells with U 73122 alone is sufficient to completely abrogate the stress-induced $\mathrm{Ca}^{2+}$ wave, with only an increase in $\left[\mathrm{Ca}^{2+}\right]_{\mathrm{i}}$ being observed in the target cell (Charles et al., 1993; Venance et al., 1997). This is in contrast to the results of our study. For cells treated with up to $10 \mu \mathrm{M} \mathrm{U} 73122$ for 30 min before mechanical stress, we observed a slowing of $\mathrm{Ca}^{2+}$ wave propagation rate and a reduction of $\Delta\left[\mathrm{Ca}^{2+}\right]_{i}$, but not complete abolition of the $\mathrm{Ca}^{2+}$ wave, similar to the results of Figure 7.

It is interesting to note that several roles for the NO-G-kinase signaling pathway in the regulation of cellular $\mathrm{Ca}^{2+}$ fluxing have previously been suggested in a few cell types, with certain aspects of intracellular $\mathrm{Ca}^{2+}$ homeostasis having been reported to involve modulation by NO and/or cGMP (Clementi and Meldolesi, 1997). Recent interest has focussed on specific roles for NO-Gkinase signaling in regulating store-operated $\mathrm{Ca}^{2+}$ influx and $\mathrm{Ca}^{2+}$ influx pathways that are dependent on the state of filling of intracellular $\mathrm{Ca}^{2+}$ stores (Xu et al., 1994; Bischof et al., 1995; Mathes and Thompson, 1996; Willmott et al., 1996a) and also $\mathrm{Ca}^{2+}$ mobilization via the increased synthesis of the $\mathrm{Ca}^{2+}$ mobilizing agent cyclic ADP-ribose (Clementi et al., 1996; Willmott et al., 1996c). Cyclic ADP-ribose (cADPR) appears to release $\mathrm{Ca}^{2+}$ from ER $\mathrm{Ca}^{2+}$ stores via RyRs and is considered to be a putative modulator of calcium-induced calcium release (Galione et al., 1991). Nitric oxide has also been shown to induce $\mathrm{Ca}^{2+}$ mobilization in pancreatic $\beta$ cells independently of an increase in cADPR (Willmott et al., 1995a,b), and possibly involving the direct nitrosylation of regulatory thiol groups of the ryanodine receptor (Stoyanovsky et al., 1997). Different modes of intracellular $\mathrm{Ca}^{2+}$ regulation by $\mathrm{NO}$ and the $\mathrm{NO}-\mathrm{G}-\mathrm{kinase}$ signaling 
pathway may reflect fundamental differences in the structure and function and/or expression of participating component enzymes, phosphorylated targets of G-kinase, plasma membrane ion channels, and $\mathrm{Ca}^{2+}$ release receptor isoforms in cells.

Although NO-G-kinase signaling has been shown to increase $\left[\mathrm{Ca}^{2+}\right]_{\mathrm{i}}$ via $\mathrm{Ca}^{2+}$ mobilization and influx in several cell types, its precise contribution to cell surface receptor-coupled increases in $\left[\mathrm{Ca}^{2+}\right]_{\mathrm{i}}$ and possible involvement in intercellular communication via $\mathrm{Ca}^{2+}$ wave initiation and/or propagation are yet to be assessed in most systems. It is also noteworthy that at the present, there is little published information regarding the efficacy of the NO-G-kinase signaling pathway in increasing $\left[\mathrm{Ca}^{2+}\right]_{\mathrm{i}}$ in excitable or neuronal cells, most studies to date having been conducted in nonexcitable cells. In neurosecretory PC12 cells, it has been suggested that $\mathrm{NO}-\mathrm{G}-$ kinase signaling can evoke $\mathrm{Ca}^{2+}$ mobilization via the increased synthesis of cADPR (Clementi et al., 1996), presenting the possibility that the enzyme responsible for cADPR synthesis, ADP-ribosyl cyclase, might represent a common target for G-kinase in other excitable cells. It is noteworthy that astrocytes can synthesize cADPR extracellularly from NAD, indicating an inherent ADP-ribosyl cyclase activity for this cell type (Pawlikowska et al., 1996). It was beyond the scope of this study however, to determine whether this, or any intracellular cADPR synthesizing activity is upregulated by NOG-kinase signaling, as in sea urchin eggs (Willmott et al., 1996c) and PC12 cells (Clementi et al., 1996), or whether cADPR generated by astrocytes is effective in releasing $\mathrm{Ca}^{2+}$ from intracellular stores.

Since NO synthesis by cNOS is usually calcium-dependent (Moncada et al., 1991), a NO-induced rise in $\left[\mathrm{Ca}^{2+}\right]_{\mathrm{i}}$ may result in an amplification of NO production in cells, as previously reported (Publicover et al., 1993). Furthermore, considering a high rate of potentially unrestricted diffusion for NO, this crosstalk between $\mathrm{NO}$ and $\mathrm{Ca}^{2+}$ could give rise to $\mathrm{Ca}^{2+}$ waves, as seen in many single cells and tissues (Berridge and Dupont, 1994). Data from this study are supportive of such a mechanism operating in glia, because (1) aqueous NO and molsidomine induce an increase in $\left[\mathrm{Ca}^{2+}\right]_{\mathrm{i}}$ in glia and initiate localized intercellular $\mathrm{Ca}^{2+}$ waves; (2) mechanical stress of single glial cells evokes an increase in cytosolic NO in the target and neighboring cells; and (3) stress-induced intercellular $\mathrm{Ca}^{2+}$ waves are seemingly reliant on both the free diff usion of NO between cells and a functional NO-G-kinase signaling pathway within cells. Until recently, it was thought that intercellular $\mathrm{Ca}^{2+}$ wave propagation in cultured astrocytes was solely or predominantly via a gap junctional mode of communication. Previously, a role for NOinduced $\mathrm{Ca}^{2+}$ mobilization in intercellular $\mathrm{Ca}^{2+}$ wave propagation had not been considered in glia, although from this study (Fig. 5a,f) and other recent observations (Charles, 1998; Cotrina et al., 1998; Guthrie et al., 1999), additional gap junctionindependent modes of $\mathrm{Ca}^{2+}$ signaling, involving the release of extracellular messengers, are also likely to assist in mediating intercellular $\mathrm{Ca}^{2+}$ waves in these cells. A study supportive of a potential role for $\mathrm{NO}$ as an intercellular messenger in glial communication was however reported by Malcolm et al. (1996). In these experiments, NOS inhibition and the extracellular NO scavenger hemoglobin effectively abrogated cGMP synthesis coupled to NMDA receptor activation in mixed neuron-astrocyte cultures. Cross-talk between $\mathrm{NO}$ and $\mathrm{Ca}^{2+}$ was also suggested, because extracellular $\mathrm{Ca}^{2+}$ was required for NMDA receptorcoupled cGMP synthesis.

Although NO-G-kinase signaling and RyR-linked $\mathrm{Ca}^{2+}$ re- lease appear to be fundamentally required for stress-induced intercellular $\mathrm{Ca}^{2+}$ waves of glia, these mechanisms do not appear to play any role in the rise in $\left[\mathrm{Ca}^{2+}\right]_{\mathrm{i}}$ coupled to $\mathrm{P}_{2}$-receptor activation by ATP, which also appears to be involved in intercellular $\mathrm{Ca}^{2+}$ wave propagation (Fig. 10). Although the $\mathrm{P}_{2}$ receptorcoupled increase in $\left[\mathrm{Ca}^{2+}\right]_{\mathrm{i}}$ was substantially inhibited by $\mathrm{U}$ 73122, suggesting a role for $\mathrm{IP}_{3}$-induced $\mathrm{Ca}^{2+}$ release in the response, the increase in $\left[\mathrm{Ca}^{2+}\right]_{\mathrm{i}}$ was not affected by either an antagonizing concentration of ryanodine or by L-NMMA (Fig. 9). Further evidence for a lack of involvement of $\mathrm{NO}$ in the rise in $\left[\mathrm{Ca}^{2+}\right]_{\mathrm{i}}$ to ATP was derived from experiments with the NO probe DAF-2, in which we did not observe any increase in DAF-2 fluorescence in glia after treatment of cells with $10 \mu \mathrm{M}$ ATP (Fig. 9e).

As well as modulating $\mathrm{Ca}^{2+}$ homeostasis in glia, $\mathrm{NO}$ appears to regulate gap junction permeability, although its precise mode of action and effect on $\mathrm{Ca}^{2+}$ signaling via gap junctions are uncertain. Whether its ultimate effect is to increase or decrease gap junction permeability remains controversial (Bolanos and Medina, 1996; O’Donnell and Grace, 1997).

In conclusion, this study highlights a fundamental role for the NO-G-kinase signaling pathway in mediating intercellular $\mathrm{Ca}^{2+}$ waves in glia, with $\mathrm{NO}$ probably acting as an extracellular $\mathrm{Ca}^{2+}$ signaling messenger in this process.

\section{REFERENCES}

Berridge MJ, Dupont G (1994) Spatial and temporal signalling by $\mathrm{Ca}^{2+}$. Curr Opin Cell Biol 6:267-274.

Bischof G, Brenman J, Bredt DS, Machen TE (1995) Possible regulation of capacitative $\mathrm{Ca}^{2+}$ entry into colonic epithelial cells by $\mathrm{NO}$ and cGMP. Cell Calcium 17:250-262.

Bolanos JP, Medina JM (1996) Induction of nitric oxide synthase inhibits gap junction permeability in cultured rat astrocytes. J Neurochem 66:2091-2099.

Centemeri C, Bolego C, Abbracchio MP, Cattabeni F, Puglisi L, Burnstock G, Nicosia S (1997) Characterization of the $\mathrm{Ca}^{2+}$ responses evoked by ATP and other nucleotides in mammalian brain astrocytes. Br J Pharmacol 121:1700-1706.

Charles A (1998) Intercellular calcium waves in glia. Glia 24:39-49.

Charles AC, Dirksen ER, Merill JE, Sanderson MJ (1993) Mechanisms of intercellular calcium signaling in glial cells studied with dantrolene and thapsigargin. Glia 7:134-145.

Clementi E, Meldolesi J (1997) The cross-talk between nitric oxide and $\mathrm{Ca}^{2+}$ : a story with a complex past and a promising future. Trends Pharmacol Sci 18:266-269.

Clementi E, Riccio M, Sciorati C, Nistico G, Meldolesi J (1996) The type 2 ryanodine receptor of neurosecretory $\mathrm{PC} 12$ cells is activated by cyclic ADP-ribose. J Biol Chem 271:17739-17745.

Cotrina ML, Lin JHC, Nedergaard M (1998) Cytoskeletal assembly and ATP release regulate astrocytic calcium signalling. J Neurosci 18:8794-8804.

Feinstein DL, Galea E, Cermak J, Chugh P, Lyandvert L, Reis DJ (1994) Nitric oxide synthase expression in glial cells: suppression by tyrosine kinase inhibitors. J Neurochem 62:811-814.

Galione A, Lee HC, Busa WB (1991) $\mathrm{Ca}^{2+}$-induced $\mathrm{Ca}^{2+}$-release in sea urchin egg homogenates: modulation by cyclic-ADP-ribose. Science 253:1143-1146.

Giaume C, Venance L (1998) Intercellular $\mathrm{Ca}^{2+}$ signalling and gap junctional communication in astrocytes. Glia 24:50-64.

Goldman SA, Pulsinelli WA, Clarke WY, Kraig RP, Plum F (1989) The effects of extracellular acidosis on neurons and glia in vitro. J Cereb Blood Flow Metab 9:471-477.

Guthrie PB, Knappenberger J, Segal M, Bennett MVL, Charles AC, Kater SB (1999) ATP released from astrocytes mediates glial calcium waves. J Neurosci 19:520-528.

Kojima H, Nakatsubo N, Kikuchi K, Urano Y, Higuchi T, Tanaka J, Kudo Y, Nagano T (1998) Direct evidence of NO production in rat hippocampus and cortex using a new fluorescent indicator: DAF-2 DA. NeuroReport 9:3345-3348.

Malcolm C, Grieve A, Ritchie L, Schousboe A, Griffiths R (1996) 
NMDA receptor-mediated cGMP synthesis in primary cultures of mouse cerebellar granule cells appears to involve neuron-astrocyte communication with $\mathrm{NO}$ operating as the intercellular messenger. J Neurosci Res 45:129-142.

Mathes C, Thompson SH (1996) The nitric oxide/cGMP pathway couples muscarinic receptors to the activation of $\mathrm{Ca}^{2+}$ influx. J Neurosci 16:1702-1709.

Moncada S, Palmer RMJ, Higgs EA (1991) Nitric oxide: physiology, pathophysiology, and pharmacology. Pharmacol Rev 34:109-142.

Nedergaard M (1994) Direct signalling from astrocytes to neurons in cultures of mammalian brain cells. Science 263:1768-1771.

Newman EA, Zahs KR (1997) Calcium waves in retinal glial cells. Science 275:844-845.

O'Donnell P, Grace AA (1997) Cortical afferents modulate striatal gap junction permeability via nitric oxide. Neuroscience 76:1-5.

Pawlikowska L, Cottrell SE, Harms MB, Li Y, Rosenberg PA (1996) Extracellular synthesis of cADP-ribose from nicotinamide-adenine dinucleotide by rat cortical astrocytes in culture. J Neurosci 16:5372-5381.

Pessah IN, Stambuk RA, Cassida JE (1987) $\mathrm{Ca}^{2+}$-activated ryanodine binding: Mechanisms of sensitivity and intensity modulation by $\mathrm{Mg}^{2+}$, caffeine, and adenine nucleotides. Mol Pharmacol 31:232-238.

Petersen CCH, Berridge MJ (1994) The regulation of capacitative calcium entry by calcium and protein kinase C in Xenopus oocytes. J Biol Chem 269:32246-32253.

Poenie M (1990) Alteration of intracellular Fura-2 fluorescence by viscosity: a simple correction. Cell Calcium 11:85-91.

Porter J, McCarthy K (1996) Hippocampal astrocytes in situ respond to glutamate released from synaptic terminals. J Neurosci 16:5073-5081.

Publicover NG, Hammond EM, Sanders KM (1993) Amplification of nitric oxide signaling by interstitial cells isolated from canine colon. Proc Natl Acad Sci USA 90:2087-2091.

Putney Jr JW (1990) Capacitative calcium entry revisited. Cell Calcium 11:611-624.

Rousseau E, Smith JS, Meissner G (1987) Ryanodine modifies conduc- tance and gating behavior of single $\mathrm{Ca}^{2+}$ release channel. Am J Physiol 253:C364-C368.

Siesjo B, Zhao Q, Pahlmark K, Siesjo P, Katsura K, Folbergrova J (1995) Glutamate, calcium and free radicals as mediators of ischemic brain damage. Ann Thorac Surg 59:1316-1320.

Stoyanovsky D, Murphy T, Anno PR, Kim Y-M, Salama G (1997) Nitric oxide activates skeletal and cardiac ryanodine receptors. Cell Calcium 21:19-29.

Venance L, Stella N, Glowinski J, Giaume C (1997) Mechanism involved in initiation and propagation of receptor-induced intercellular calcium signaling in cultured rat astrocytes. J Neurosci 17:1981-1992.

Willmott NJ, Galione A, Smith PA (1995a) Nitric oxide induces $\mathrm{Ca}^{2+}$ mobilization and increases secretion of incorporated 5-hydroxytryptamine in rat pancreatic $\beta$-cells. FEBS Lett 371:99-104.

Willmott NJ, Galione A, Smith PA (1995b) A cyclic-ADP-ribose antagonist does not inhibit secretagogue-, caffeine-, and nitric oxide- induced $\mathrm{Ca}^{2+}$ responses in rat pancreatic $\beta$-cells. Cell Calcium 18:411-419.

Willmott NJ, Asselin J, Galione A (1996a) Calcium store depletion potentiates a phosphodiesterase inhibitor- and dibutyryl cGMP-evoked $\mathrm{Ca}^{2+}$ influx in rat pituitary $\mathrm{GH}_{3}$ cells. FEBS Lett 386:39-42.

Willmott NJ, Choudhury Q, Flower RJ (1996b) Functional importance of the dihydropyridine-sensitive, yet voltage-insensitive store-operated $\mathrm{Ca}^{2+}$ influx of U937 cells. FEBS Lett 394:159-164.

Willmott N, Sethi JK, Walseth TF, Lee HC, White AM, Galione A (1996c) Nitric oxide induces calcium mobilization via activation of the cyclic-ADP-ribose pathway. J Biol Chem 271:3699-3705.

Xu X, Star RA, Tortorici G, Muallem S (1994) Depletion of intracellular $\mathrm{Ca}^{2+}$ stores activates nitric oxide synthase to generate cGMP and regulate $\mathrm{Ca}^{2+}$ influx. J Biol Chem 269:12643-12653.

Zimanyi I, Buck E, Abramson JJ, Mack MM, Pessah IN (1992) Ryanodine induces persistent inactivation of the $\mathrm{Ca}^{2+}$ release channel from skeletal muscle sarcoplasmic reticulum. Mol Pharmacol 42:1049-1057.

Zweifach A, Lewis RS (1993) Mitogen-regulated $\mathrm{Ca}^{2+}$ current of $\mathrm{T}$ lymphocytes is activated by depletion of intracellular $\mathrm{Ca}^{2+}$ stores. Proc Natl Acad Sci USA 90:6295-6299. 